\title{
Role of Liver-Mediated Tolerance in Nanoparticle-Based Tumor Therapy
}

\author{
Maximiliano L. Cacicedo ${ }^{1,+}$ (), Carolina Medina-Montano ${ }^{2,+}$, Leonard Kaps $^{3}$, Cinja Kappel ${ }^{2}$, \\ Stephan Gehring ${ }^{1}$ and Matthias Bros ${ }^{2, *}$ \\ 1 Children's Hospital, University Medical Center, Langenbeckstrasse 1, 55131 Mainz, Germany; \\ mcaciced@uni-mainz.de (M.L.C.); Stephan.Gehring@uni-mainz.de (S.G.) \\ 2 Department of Dermatology, University Medical Center Mainz, Langenbeckstrasse 1, 55131 Mainz, \\ Germany; gmedinam@students.uni-mainz.de (C.M.-M.); cinkappe@uni-mainz.de (C.K.) \\ 3 Department of Medicine, University Medical Center Mainz, I. Langenbeckstrasse 1, 55131 Mainz, Germany; \\ lenardkaps@googlemail.com \\ * Correspondence: mbros@uni-mainz.de; Tel.: +49-6131-17-9846 \\ + These authors contributed equally to this work.
}

Received: 4 August 2020; Accepted: 26 August 2020; Published: 28 August 2020

\begin{abstract}
In the last decades, the use of nanocarriers for immunotherapeutic purposes has gained a lot of attention, especially in the field of tumor therapy. However, most types of nanocarriers accumulate strongly in the liver after systemic application. Due to the default tolerance-promoting role of liver non-parenchymal cells (NPCs), Kupffer cells (KCs), liver sinusoidal endothelial cells (LSECs), and hepatic stellate cells (HSCs), their potential role on the immunological outcome of systemic nano-vaccination approaches for therapy of tumors in the liver and in other organs needs to be considered. Concerning immunological functions, KCs have been the focus until now, but recent studies have elucidated an important role of LSECs and HSCs as well. Therefore, this review aims to summarize current knowledge on the employment of nanocarriers for immunotherapeutic therapy of liver diseases and the overall role of liver NPCs in the context of nano-vaccination approaches. With regard to the latter, we discuss strategies on how to address liver NPCs, aiming to exploit and modulate their immunological properties, and alternatively how to avoid unwanted engagement of nano-vaccines by liver NPCs for tumor therapy.
\end{abstract}

Keywords: nano-vaccine; immunotherapy; tumor therapy; liver sinusoidal endothelial cells; Kupffer cells; hepatic stellate cells; tumor-associated macrophages

\section{Introduction}

During the last decades, the development of nanoparticles (NPs) that deliver drugs and biologicals in a cell type-specific manner has received growing interest as a new therapeutic strategy in cancer therapy [1]. Targeting may be an intrinsic property of the NP due to its size and surface properties [2] or can be conferred by conjugated moieties that bind target cell surface receptors, including antibodies, derivatives of natural ligands, and aptamers [3,4].

In case of tumor therapy, NPs may be designed to target tumor cells directly and to deliver cytotoxic drugs or biologicals [5]. More recently, direct targeting of regulatory immune cell types within the tumor microenvironment (TME), comprising tumor-associated macrophages (TAM), myeloid-derived suppressor cells (MDSCs), and regulatory T cells (Treg) that inhibit other immune cells both within the TME and in the periphery, has proven to be an interesting approach [6]. In that case, nano-vaccines may contain a payload, which either acts in a cytotoxic manner or serves to reprogram a regulatory immune cell to counteract tumor tolerance, e.g., by inhibiting the activity of transcription factor STAT 
(signal transducer and activator of transcription) 3 that promotes expression of protolerogenic proteins like IL-10 [7]. Nano-vaccines aim to exert tumor-specific immune responses by co-delivery of a tumor antigen and an adjuvant to antigen-presenting cells (APCs) like dendritic cells (DCs), which constitute the most important APC population [8,9].

Topical nano-vaccination delivery, e.g., via the skin, may induce predominantly skin-targeting $\mathrm{T}$ effector cells. Hence, systemic delivery of a nano-vaccine may be preferable for therapy of metastatic tumors in order to induce T effector cells that may home any organ [10]. However, so far, virtually all types of functionalized NPs have been reported to accumulate in the liver for considerable extent after systemic application [11]. Therefore, unless the liver is the intended target organ of functionalized $\mathrm{NP}$, for example in the case of treatment of liver fibrosis [12] or hepatocellular carcinoma (HCC) [13], the role of the liver as an obstacle in nano-vaccination needs to be elucidated.

This review aims to summarize knowledge on the immunoregulatory activity of liver non-parenchymal cells (NPCs) with a focus on liver sinusoidal endothelial cells (LSECs) and Kupffer cells (KCs) and on their interaction with systemically applied NP. In case of nano-vaccines that are employed to induce, e.g., antitumor responses, unwanted engagement by liver NPCs may result in tolerance-promoting effects. However, NP-based immunotherapeutic strategies may also aim to exploit the default tolerogenic function of liver NPCs for therapy of autoimmune diseases and allergies. Moreover, functionalized NPs have been used to reprogram liver macrophages with regulatory functions towards a proinflammatory state for tumor therapy.

\section{NPC Populations of the Liver Contribute to its Tolerogenic Activity}

The liver constitutes an important tolerance-promoting organ which is conferred by the concerted activity of non-parenchymal liver cell populations [14]. Antigen-specific tolerance in the liver is largely mediated by KCs that constitute the liver-resident macrophage population and by LSECs. Liver DCs have been ascribed an overall tolerogenic role as well, nicely reviewed by Dou et al. [15]. So far, it is well established that NPs engage KCs [16]. However, the role of LSECs in this regard and the consequences of antigen delivery to KCs and LSECs concerning their effect on immune responses have scarcely been addressed yet. Further, hepatic stellate cells (HSC), which also exert important immune-relevant functions, were shown to engage NPs as well [17].

\subsection{Immunological Role of LSECS}

LSECs represent about $60 \%$ of liver NPCs and are strategically placed lining the hepatic sinusoid [18]. Therefore, LSECs are the first liver cell type that may engage pathogens, immune complexes, and circulating lymphocytes. LSECs possess fenestrations acting as a sieve, which allow the exchange of fluid, solutes, and particles between the blood and the space of Disse [19] (Figure 1). LSECs act as scavengers to clear (potentially dangerous) macromolecules from blood. In addition, as described below, LSECs possess both innate and adaptive immune functions and are highly acknowledged as an important player in liver immunity, including HCC development and progression [18]. Most importantly, under homeostatic conditions, antigen presentation by LSEC leads to tolerance induction in $\mathrm{CD}^{+}$cells and to the induction of immunosuppressive $\mathrm{CD} 4^{+}$regulatory T cells (Treg) [20]. 


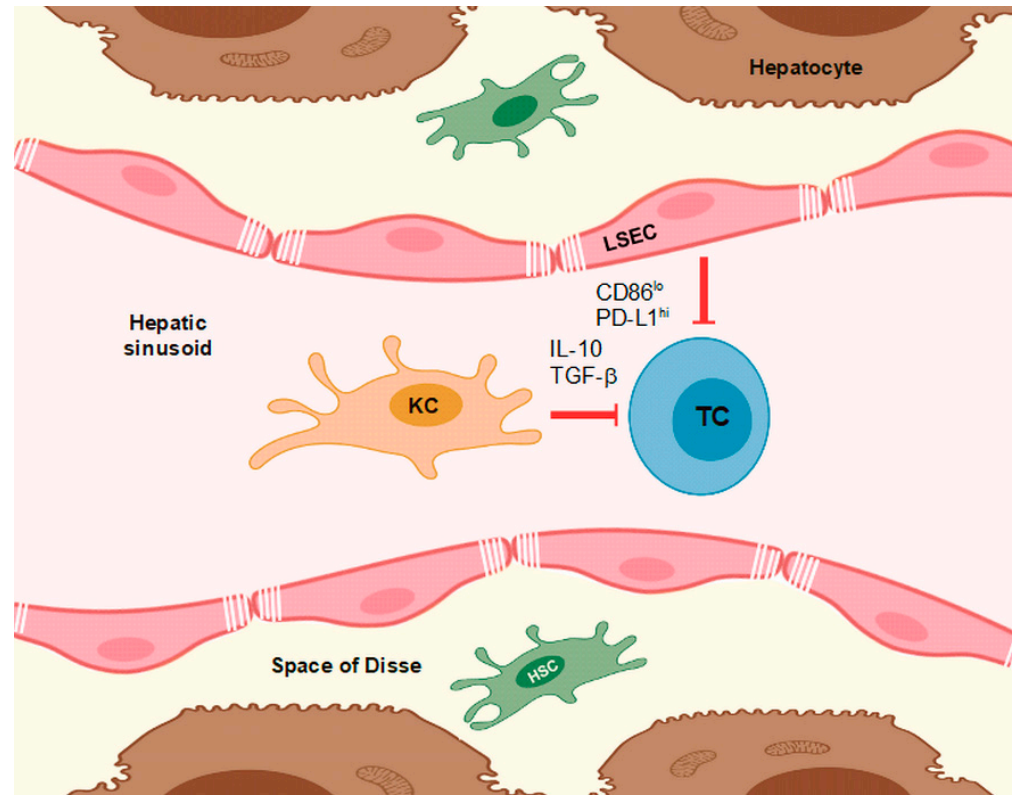

Figure 1. Kupffer cells (KCs) and liver sinusoidal endothelial cells (LSECs) by default confer T cell tolerance by presenting antigens in a non-stimulatory context, characterized by low expression of costimulatory receptors like CD86 but high expression of PD-L1 and by the release of anti-inflammatory cytokines like interleukin (IL)-10 and tumor growth factor (TGF)- $\beta$.

\subsection{Immune-Relevant Properties of LSEC}

\subsubsection{Phenotype}

Phenotypic characterization of LSEC requires combined detection of several surface receptors. LSECs are the only liver-resident cell population that expresses Fc $\gamma$ RIIb2 (CD32b) [21], and besides, KCs express the mannose receptor CD206 at high levels [22]. CD45 is highly expressed on periportal LSECs, lowly expressed on midlobular LSECs, and is not apparent on centrilobular LSECs $[23,24]$. Therefore, differential expression of CD45 in LSECs allows for delineation of their localization within the liver. CD31 serves as a panendothelial cell marker [25]. In addition, LSECs were shown to express von-Willebrand-Factor (VWF), the scavenger receptors Stabilin-1 and -2, vascular endothelial growth factor receptors (VEGFR) 2 and 3, the CD44 homolog lymphatic vessel endothelial receptor (LYVE) 1, and the adhesion receptor CD146 $[18,20,23,26]$. Accordingly, LSECs can be phenotypically described as $\mathrm{CD} 31^{+} \mathrm{CD} 146^{+} \mathrm{CD} 32 \mathrm{~b}^{+}$.

\subsubsection{Endocytic Capacity}

LSECs have the highest endocytotic capacity of all human cell types [18]. Their clathrin-dependent endocytic machinery confers efficient uptake of foreign and physiological (waste) products, like connective tissue macromolecules, heparin, lysosomal enzymes, modified proteins and lipoproteins, and soluble IgG complexes [27]. LSECs are equipped with various endocytosis receptors, including scavenger receptors class A (SCARA1-5), B (SCARB1-3), E (SCARE1-2), and $\mathrm{H}$ (stabilin-12) $[18,23,28]$. As mentioned above, LSECs also express different C-type lectin receptors (CLRs). These receptors are predominantly expressed by professional APCs in a population-specific manner [29] and in a CLR-type-specific manner recognizing pathogen-specific glycoproteins [30], endogenous damage-associated molecular patterns derived from dead cells [31], and proteins with a tumor-dependently altered glycosylation pattern [32]. As shown for APCs, both the type of CLR engaged as well as concomitant triggering of other types of receptors, like TLR (Toll-like receptor), determine whether CLR engagement yields stimulatory or inhibitory signaling [33]. 
LSECs express the CLR CD206, which is also apparent on monocytes/macrophages and conventional DCs [34], and L-SIGN (liver/lymph node-specific intercellular adhesion molecule (ICAM)-3 grabbing non-integrin), also known as DC-SIGNR (DC-SIGN-related protein; CD209L), and LSECtin [35]. DC-SIGNR/L-SIGN is a homolog of DC-SIGN (CD209) which is expressed predominantly by $\mathrm{CDC}$ and by some macrophage populations [36]. Besides LSECs, macrophages [37], including KC [38] were reported to express LSECtin too. So far, L-SIGN and DC-SIGN were demonstrated to bind largely the same pathogen-associated glycoproteins $[39,40]$, whereas LSECtin was shown to engage only a subset of viruses that bind DC-SIGN/DC-SIGNR [35].

LSECs recognize and endocytose IgG-containing immune complexes via Fc $\gamma$ RIIb2 [18,20,23,28]. $\mathrm{Fc} \gamma \mathrm{RIlb}$ is the only Fc receptor that induces inhibitory cell signaling upon engagement [21]. As described by Tanikagi and collegues, stimulation of activating $\mathrm{F}_{\mathrm{C}} \gamma \mathrm{R}$ in endothelial cells, vascular smooth muscle cells, and monocytes/macrophages causes a variety of cellular responses that may contribute to vascular disease pathogenesis [41].

\subsubsection{Immune Functions}

LSECs express various PRR (pathogen-associated recognition receptors), including TLR2-4, TLR6, TLR8, and TLR9 [42] as well as NOD (nucleotide binding oligomerization domain containing) 1/2 receptors [43], and produce innate cytokines in response to stimulation (e.g., tumor necrosis factor (TNF) $\alpha$, IL-6, and IL-1 $\beta$ ). LSECs exert APC activity during immune surveillance and liver inflammation and predominantly contribute to peripheral immune tolerance [44]. The APC activity of LSECs has been attributed to the constitutive and inducible expression of several surface markers and costimulatory molecules associated with professional APCs, such as major histocompatibility complex (MHC) I and II [45], ICAM (intercellular adhesion molecule) 1 [46], vascular cell adhesion protein (VCAM) 1 [47], CD40, CD80, CD86 [48], L-SIGN, and vascular adhesion protein (VAP) 1 [23]. Of note, LSECs can present antigens of exogenous origin via MHCII to $\mathrm{CD}^{+}{ }^{+} \mathrm{T}$ cells [49] and via MHCI to CD8 ${ }^{+}$ $\mathrm{T}$ cells [50], termed cross-presentation. Cross-presentation has also been reported to enable LSECs to present antigens derived from internalized apoptotic tumor cells to CD8 ${ }^{+}$cells leading to $\mathrm{T}$ cell tolerance [50]. LSECs express the lectin galectin-1, which is known to bind and to induce apoptosis in activated T cells, resulting in immunological tolerance as well [19]. Of note, besides LSECs, only subpopulations of DCs are capable of cross-presenting antigens derived from internalized material [51]. In the case of LSECs, their tolerogenic phenotype as characterized by programmed death-ligand 1 (PD-L1) $^{\text {high }} \mathrm{CD} 80 / \mathrm{CD} 86^{\text {low }}$ expression by default supports induction of CD8 ${ }^{+} \mathrm{T}$ cell tolerance [52]. Further, lipopolysaccharide-activated LSEC can induce naïve $\mathrm{CD} 4^{+} \mathrm{T}$ cells to produce interferon (IFN)- $\gamma$, interleukin (IL)-4, interleukin (IL)-10, and tumor growth factor (TGF)- $\beta$ but do not induce a stable T helper cell type (Th)1 or Th2 phenotype [53]. Besides, LSECs were reported to diminish the functional activity of Th1 and Th17 via PD-L1 and IL-10 [54]. Moreover, LSECs were shown to induce expression of the anti-inflammatory cytokine IL-10 in Th1 without affecting their IFN- $\gamma$ production [55]. Thereby, LSECs also contribute to impairing autoreactive CD4 ${ }^{+} \mathrm{T}$ cells in the periphery. Moreover, as compared to KCs, LSECs are more efficient at inducing differentiation of naïve $\mathrm{CD} 4^{+} \mathrm{T}$ cells to CD25+Foxp $3^{+}$Treg due to their ability to secrete TGF- $\alpha$ and to tether exogenous TGF- $\beta$ [49,52]. However, stimulation of LSECs with TLR1/2 ligands resulted in a profound increase in their T cell stimulatory activity, accompanied by upregulation of APC surface markers and a release of IL-12 promoting Th1 and cytotoxic T lymphocyte (CTL) induction [56].

\subsubsection{Targeting of LSEC with Nanocarriers}

Nano-vaccines can be used for treatment of allergies or autoimmune diseases aiming either to promote antigen-specific immune tolerance or to redirect an adaptive immune response. Concerning the former strategy, targeting of LSECs (and KCs) which promote antigen-specific tolerance to selfor foreign antigens by default is an attractive option [57]. Due to inhibitory signaling evoked by triggering Fc $\gamma$ RIIb on LSECs, a nano-vaccine designed to induce tolerance may not necessarily require 
co-delivery of an anti-inflammatory moiety. However, the latter may be necessary to override any potential activating signal induced by addressing a given receptor [58].

The potential of LSECs as a target for immunotherapy has scarcely been issued yet. Finding a way to adjust the NP surface for LSEC targeting is a universal approach to improve the efficacy of NP targeting and drug delivery to endothelial cell types in the liver [4]. LSECs are specialized in the uptake of soluble material and of immune complexes which have a mean diameter of about $40 \mathrm{~nm}$, at a range from 20-150 nm [21]. KCs endocytose material as well but, due to Fc-receptor (FCR) and complement receptor (CR) expression, are also equipped to phagocytose pathogens, including bacteria and fungi [59]. Therefore, nano-vaccines intended to target LSECs should be of a smaller size $(\leq 150 \mathrm{~nm})[21]$.

LSEC-focused NP delivery may require targeting of endocytic surface receptors expressed by this cell population at high density, for example, CD206 [22]. However, this receptor is also expressed by KCs, other macrophages, and conventional DC populations throughout the body [59]. On the contrary, so far, the CLR L-SIGN has been reported as expressed by LSEC only [49]. Nonetheless, since DC-SIGN is homologous to L-SIGN, receptor ligands to be used as LSEC-targeting moieties may also address DCs and macrophages [35]. Engagement of CD206 promotes cross-presentation of derived antigens and may evoke stimulatory cellular signals that enhance APC activity [40]. So far, signaling consequences of triggering CD206 on LSECs as well as L-SIGN have not been studied. LSECs also express Fc $\gamma$ RIIb at high extents to internalize immune complexes [60]. This Fc receptor is the only one which transmits an inhibitory signal upon engagement and, therefore, may contribute to the default tolerance-promoting state of LSECs [21]. The potential of LSEC-focused nano-vaccination to reestablish tolerance as required for effective treatment of autoimmune diseases and allergies has also been scarcely analyzed. So far, only one study has been published describing the use of an LSEC-targeting nano-vaccine with therapeutic efficacy in a model of ovalbumine-induced asthma [57].

It has been demonstrated that the default protolerogenic state of LSECs can be overcome by treatment with different stimuli, including TLR ligands. At an activated state, LSECs induce T effector cells [49]. This property might be of general interest with regard to the development of immunotherapeutic strategies for treatment of (liver) cancer, including tumor metastasis in the liver, as well as for treatment of (chronic) infections in this organ [57].

\subsection{Liver Macrophages Maintain Tolerance under Homeostatic Conditions}

\subsubsection{KCs Are the Main Macrophage Population under Homeostatic Conditions}

KCs have been described as the biggest macrophage population residing in the liver. These resident macrophages are a fundamental pillar for intrahepatic and general innate immunity. Actually, KCs represent around $80 \%$ of all tissue macrophages in the body [61]. KCs are mostly located in the liver sinusoids, an ideal place to display their role as sentinels of the immune system. However, recently, it has been described that KCs extend their cell body to the space of Disse where they can interact with HSC and hepatocytes [62]. This kind of interaction is important from a functional point of view as KCs are responsible, e.g., for the transfer of iron from apoptotic red blood cells to hepatocytes [63]. Very recently, a study using single-cell RNA sequencing analyzed the differences between intrahepatic monocyte/macrophage populations [64]. It is well-recognized by now that nonmigratory macrophages derived from embryogenic roots constitute KCs.

Following injury, there is an influx of monocyte-derived macrophages (MoMFs) into the liver (Figure 2). These macrophages then acquire the KC-specific genetic program [62]. It remains under discussion whether monocyte-derived macrophages in the liver need to be considered as a KC subpopulation $[64,65]$. MoMFs display pro-inflammatory functions and can be identified by their distinct phenotypic marker profile (HLA-DR ${ }^{+} \mathrm{CD} 25^{+} \mathrm{CD} 86^{+}$) in human liver tissue. MoMFs remove protein complexes and particulate material and apoptotic cells from the blood by phagocytosis [66]. Their function complements LSECs, generating an efficient barrier to avoid penetration by pathogens 
inside the liver through the portal vein [67]. In comparison, KCs confer immunomodulatory functions and can be identified by markers like CD163, CD206, and CD209 [6]. Besides, KC expresses MARCO (macrophage receptor with collagenous structure) [68]. The expression of MARCO in the tumor microenvironment (TEM) has been related to poor prognosis in different cancers [64].

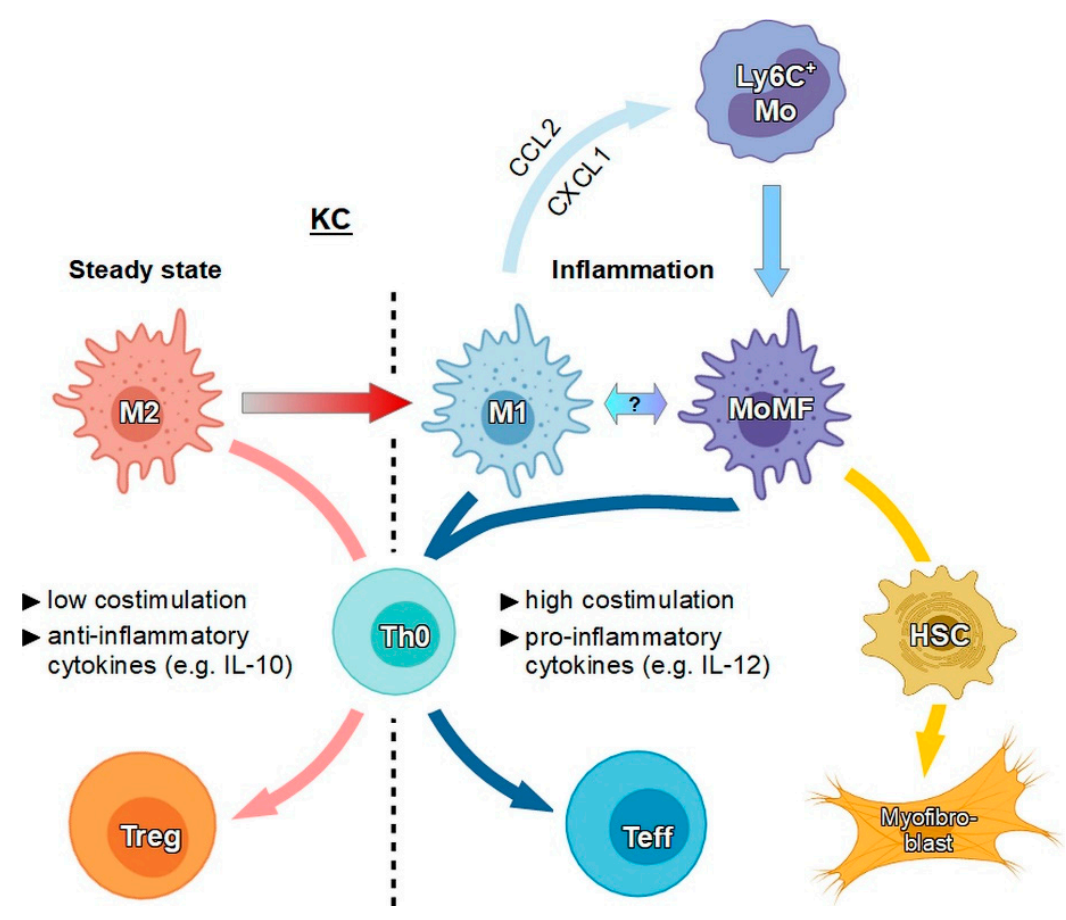

Figure 2. Under steady state conditions, KCs exhibit a protolerogenic M2-like immunophenotype and convert T cells, as shown for naïve CD4+ T cells (Th0), towards Treg due to low co-stimulation and secretion of anti-inflammatory cytokines. In response to stimulation, KCs may acquire an immunogenic M1-like state and may attract $\mathrm{Ly}^{+}$monocytes (Mo), which then differentiate to monocyte-derived macrophages (MoMFs). The exact relation between KCs and MoMFs is unclear yet. Both immunogenic M1-like KCs and MoMFs induce T effector cells (Teff) since they express costimulatory receptors and pro-inflammatory cytokines at high extents. Furthermore, MoMFs induce trans-differentiation of hepatic stellate cells (HSCs) towards myofibroblasts.

Although the findings on liver function and immunity in mice usually fit well with human liver, those markers used to identify macrophage populations are different. Hepatic macrophage markers, for example, are commonly $\mathrm{CD} 45^{+} \mathrm{F} 4 / 80^{+}$. Of these, MoMFs express markers like CD16, CD32, and CD11c, while KCs express CD206 and CD209 [69-71].

2.3.2. KCs Promote Tolerance by Default but Exert Pro-Inflammatory Activity in Case of Liver Inflammation

Macrophages are equipped with various types of danger receptors that enable sensing and recognition of pathogens, such as scavenger receptors, TLR, retinoic acid-inducible gene (RIG)-like receptors (RLR), NOD-like receptors (NLR), and CLR [66]. KCs are equipped with TLR1-9 [72], complement receptors (CR1, CR3, and CR4) [73], and scavenger receptors including class AI/II [74].

Under steady state conditions, KCs are of a M2-like phenotype [75], characterized by low expression levels of MHCII, CD80, CD86, and CD40 and by generation of anti-inflammatory IL-10 at considerable extents [76] (see Figure 2). Antigen presentation by KC leads to $\mathrm{CD}^{+} \mathrm{T}$ cell arrest and Treg expansion [77] as well as inhibition of antigen-specific T effector cells that have been induced by other APCs [69]. Furthermore, KCs also produce immunomodulatory mediators, such as IL-10, TGF- $\beta$, galectin-9, PD-L1, and PD-L2 during hepatitis infection, which suppress antiviral T cell 
responses [69,78]. In summary, all of these effects elicit tolerogenic immunity [79]. IL-10 release also reduces the production of TNF- $\alpha$, IL-6, and other cytokines contributing to tolerance [80]. Altogether, KCs are self-renewing, resident, and principally nonmigratory macrophages that serve as sentinels in the liver [65] and serve to promote tolerance by default [81]. Thus, immune responses against harmless antigens like those derived from the diet or from gut microbiota can be avoided [82]. However, under conditions like liver inflammation and fibrosis, KCs may repolarize towards a M1-like proinflammatory phenotype [77]. Above, activation of KC by stimulation of TLR also leads to an increase in CCL2 and chemokine (C-X-C motif) ligand (CXCL) 1 levels, attracting MoMFs [65]. In the case of MoMFs, once a foreign macromolecule is recognized by a danger receptor, a set of inflammatory cytokines like TNF- $\alpha$, IL-1 $\beta$, IL-6, IL-12, IL-15, and IL-18 and chemokines like chemokine (C-C motif) ligand (CCL)2-5 [77,83] are released. As a consequence, these mediators induce recruitment of several immune cells to the liver, like neutrophils, natural killer T (NKT) cells, and MoMFs, starting a cascade of immunological responses.

In addition, when KCs are depleted in the course of disease or liver injury, MoMFs have the capacity to regenerate liver macrophages by differentiating to KCs [84]. However, this regenerative situation may lead also to uncontrollable inflammation, which increases the probability of inducing liver damage. Meanwhile, KCs can promote tissue repair but may also induce aberrant tissue repair, resulting in fibrosis and cancer $[65,69]$.

\subsubsection{Targeting Hepatic Macrophage Populations with Nanocarriers for Immunotherapy}

Liver macrophages work as a sink for all particulate material that circulates within blood. As an immediate consequence, targeting a specific macrophage population within the liver can be a difficult task. In general, NP internalization by hepatic macrophages was shown to be driven by different mechanisms including macropinocytosis, clathrin- as well as caveolin-mediated endocytosis, and additional endocytotic pathways [85]. There are two major cell type-targeting strategies: passive and active targeting. Passive targeting includes the modulation of NP properties, for example, size and surface charge, to increase its probability to reach the specific target cell.

\section{Passive Targeting}

The uptake of non-functionalized NPs by macrophages has been demonstrated to depend mainly on NP size and on macrophage phenotype. In a recent study, human-derived monocytes were differentiated in vitro towards macrophages using different cytokine cocktails, inducing so-called M1and M2-like phenotypes, respectively [86]. Regardless of the macrophage phenotype, uptake of gold NP was much higher for NPs with a larger diameter $(100 \mathrm{~nm})$ than smaller NPs $(15 \mathrm{~nm}$ and $60 \mathrm{~nm})$. Notably, for each given type of NP, a big difference in uptake between differentially polarized macrophages was observed: those with a regulatory phenotype (M2 type) showed more than $40 \%$ higher uptake than proinflammatory macrophages (M1 type). In agreement, KCs were found to internalize relatively large NPs (>200 $\mathrm{nm} \varnothing)$ in vivo [85]. An interesting approach to assessing the intrinsic targeting properties of NP in a systemic manner, being mainly performed with liposomes, is the creation of formulation libraries in which several structural changes of NP are tested comparatively, such as changes in the type of phospholipids being used. Cell distribution studies allowed for identification of formulations that preferably accumulate in KC [87]. The preference in NP accumulation by regulatory macrophages has been exploited to induce tolerance against autoimmune diseases. In this regard, NPs loaded with self-antigen were directed to $\mathrm{KCs}$, which in turn presented the antigen and induced $\mathrm{T}$ cell tolerance $[88,89]$.

\section{Active Targeting}

NP functionalized with the sugar moiety mannose intending to target the main mannose binding receptor CD206 (also) expressed by KCs resulted in significantly increased binding to that cell population $[78,90,91]$. Dual targeting using two different oligosaccharides as ligands for mannose/fucose 
receptors has proven to induce an accumulation of NPs in murine KCs. Attachment of these ligands, named 4-aminophenyl- $\alpha$-D-mannopyranoside (APM) and 4-aminophenyl- $\beta$-L-fucopyranoside (APF), to liposomes has been used to study the contribution of $\mathrm{KC}$ to the accelerated blood clearance phenomenon and for specific depletion of KC [92,93]. However, as mentioned above, CD206 is also expressed by DCs and LSECs, and folate can bind to receptors on normal epithelial cells and tumor cells [94], suggesting that targeting of either receptor may not yield macrophage-specific NP uptake. As an alternative approach, novel synthetic peptides have been developed to target regulatory macrophages in a more exclusive manner. To this end, a peptide library selection approach was followed which allowed identification of a unique targeting ligand for murine M2-type macrophages, named M2pep. M2-type tumor associated macrophages (TAM) have been targeted using M2pep-modified liposomes to deplete them from melanoma [95]. Another study using HCC cells has studied M2pep binding also to TAMs, showing selectivity for M2-type macrophages. The authors also reported about M2pep binding to KCs, though binding to TAM was higher in comparison [96]. In summary, specific targeting to liver macrophage populations has been proven to be very challenging though extremely necessary to achieve different therapeutic objectives such as NP accumulation for specific drug delivery to induce or avoid immune responses or to modulate M1/M2 macrophage balance.

\section{Reprogramming of Liver Macrophages}

Macrophage plasticity is still a challenging field of study and is of huge interest for therapeutic purposes. Macrophages present in different tissues can modulate their phenotype with dependency on the surrounding environment [97]. Based on this fact, therapeutic strategies are followed, aiming to induce a shift between pro-inflammatory and tolerogenic phenotypes. Concerning the capability of NPs to reprogram hepatic macrophages, silica NPs have been reported to induce the release of TNF- $\alpha$ and IL-1 $\beta$ [98]. In another study, peptide-functionalized gold NPs have been the cause of liver macrophage polarization [99]. In that study, the bioactive tripeptides RGD and GLF were attached to the NP surface. RGD-NP induced a downregulation of both M1 and M2 surface markers. In contrast, GLF-NP upregulated M1 and M2 markers. Other strategies aim to deliver compounds that can activate/inhibit inflammatory pathways or can induce macrophage polarization. Although there is still quite the uncertainty about different molecular interactions involved in the complexity of macrophage functions, some progress has raised interest in this regard. For instance, peroxisome proliferator-activated receptor (PPAR-) $\gamma$ has emerged as a master regulator for macrophage polarization [100]. Recent studies reported that upregulation of PPAR- $\gamma$ shifts macrophages polarization from a M1- to a M2-like phenotype. A switch in macrophage polarization was associated with the interaction between PPAR- $\gamma$ and nuclear factor kappa B (NF-kB) p65 signaling pathways [101]. This report showed that manipulation of PPAR- $\gamma$ activity can modulate M1/M2 macrophage polarization, having the potential to prevent development of nonalcoholic fatty liver disease (NAFLD). Understanding of these immunomodulatory functions in liver macrophages can lead to the development of novel therapeutic strategies based on macrophage polarization.

Strategies involved in adapting macrophages to acquire a more inflammatory phenotype could be valuable for further development of immunotherapeutic cancer approaches.

\subsection{Immunorelevant Functions of HSC}

HSCs are mesenchymal cells and compromise about 5-8\% of all liver cells [102]. HSCs fulfill a variety of tasks depending on their state as either activated or so-called quiescent HSC. Normally, HSCs are in a quiescent state and constitute the major storage site of vitamin A, secrete extracellular matrix components, and play a role in intercellular communication $[103,104]$. After their activation, as induced by liver injuries, HSCs transdifferentiate into myofibroblasts [105]. As such, they produce a lot of collagen, which explains their implication in the pathogenesis of liver fibrosis [106]. Besides, activated HSCs also influence the formation and the progression of HCC [107]. In addition, due to 
their localization near KCs and LSECs in the perisinusoidal space (see Figure 1), HSCs play a role in hepatic immune responses, which qualifies them as a target for immunotherapy.

\subsubsection{Immune Functions}

Under homeostatic conditions, HSCs primarily contribute to the livers' immune tolerance, similar to other cell types found within the liver [108]. However, it is known that HSCs also express several TLRs which, when triggered, can induce the release of pro-inflammatory cytokines shaping the livers' response to injury or infection [109-111]. Besides a direct innate immune reaction by HSCs [112,113], this cell population also constitutes an important modulator of immune responses by interacting with immune cells like neutrophils [114], macrophages [115], DCs [112], and LSECs [116] via pro-inflammatory or inhibitory cytokines and trogocytosis, a process in which molecules are exchanged between cells [112]. Furthermore, it has been shown that activated HSCs can act as nonconventional APCs. In this regard, Winau and colleagues demonstrated that HSCs not only are capable of activating $\mathrm{CD}^{+} \mathrm{T}$ cells $[117,118]$ but also showed cross-priming capability, resulting in activation of $\mathrm{CD} 8^{+} \mathrm{T}$ cells [119]. These various properties of HSCs to shape the livers' immune response offer new therapeutic opportunities for liver diseases.

\subsubsection{HSC as a Target for Nanocarriers for Immunotherapy}

The liver is the main organ in which systemically applied NPs accumulate and are cleared from the body. As outlined above, KCs and LSECs are considered the key players in this regard, but HSCs have also been reported to engulf NPs, albeit to a lesser extent, partly because their location hardly allows any contact with blood-borne particles before these would reach KCs or LSECs [17]. However, active targeting of HSCs by NPs conjugated with moieties that address surface receptors expressed at high density by this cell type may be an effective approach. Popular surface receptors for active targeting of HSCs are the mannose-6-phosphat (M6P) receptor [120], the retinol binding protein (RBP) receptor [121], the platelet-derived growth factor (PDGF) receptor [122], and the collagen type VI receptor [123]. All of these receptors have been targeted successfully in vivo and/or in vitro mainly with liposomal NPs sized between 15 and $400 \mathrm{~nm}(\varnothing)$, aimed to decrease the fibrotic activities of HSCs. Most of the published results about HSCs targeted in the context of NP-mediated immunotherapy are about the improvement of therapy for liver fibrosis, and several nanoparticular systems are already tested in clinical trials [12,124,125]. Although studies about nanocarriers targeting HSCs for the treatment of HCC are missing, by now, this could be a future approach. The potential of HSCs to act as APCs and their ability to cross-talk with other immune cells might open up new possibilities when it comes to the initiation or modulation of an immune response. Depending on the intention, the right type of actively targeted nanocarrier combined with a suitable drug, antigen, and/or adjuvant could vastly improve the therapy of liver fibrosis and presumably the treatment of HCC as well. The antifibrotic or antitumor effects of such types of nanomedicine could even be amplified if several liver cell types, interfering with each other, are targeted at the same time, leading to an effective multi-faceted approach.

Altogether, besides KCs and LSECs, HSCs have also become a target for NP-based (immuno)therapeutic approaches because of their implication in the onset and progression of liver fibrosis and HCC combined with their various immunological functions.

\section{HCC-Risk Factors and Current Treatment}

The liver can be considered an organ with high physical resilience as it possesses a remarkable capacity to regenerate from acute conditions, e.g., hepatectomy or drug-induced-liver injury [126]. Under chronic conditions, its regenerative capacity becomes a two-sided sword. It consists of parenchymal and non-parenchymal cells, while hepatocytes are the most abundant $(>80 \%)$ and functionally active cells [127]. Albeit debates are still ongoing, there is mounting evidence that HCC derives primarily from transformed hepatic progenitor cells and hepatocytes as a consequence of accumulating genetic mutations and epigenetic alterations [128]. 


\subsection{Risk Factors for HCC}

The chronic component in the development of HCC is underlined by the fact that HCC occurs almost always (approximately 90\%) in cirrhotic livers [129]. Cirrhosis can be considered a precancerous condition and represents the most important risk factor of HCC. Accordingly, cirrhotic patients run a yearly risk of approximately 5\% for the development of HCC. Cirrhosis is characterized by an excessive accumulation of scare tissue, primarily collagen, in the liver. This severe distortion of the parenchymal and vascular structure represents the end-stage of every chronic liver disease. Other HCC-promoting risk factors are viral hepatitis B (and C), which together account globally for $80 \%$ of HCC cases $[130,131]$.

Furthermore, metabolic liver disease has become the most common liver disease in developed countries and an increasing major risk factor for HCC [132,133]. Nonalcoholic fatty liver disease (NAFLD) had the highest population-attributable fraction of $37 \%$ for HCC [134]. In contrast to other underlying diseases, HCC occurs frequently in the absence of cirrhosis in NAFLD. A US population-based study of 1500 patients with HCC demonstrated that non-cirrhotic patients with NAFLD-associated HCC had a fivefold risk of having HCC compared to non-cirrhotic patients with hepatitis C virus (HCV)-associated HCC [135]. Diabetes, which displays an increasing incidence in the Western World, is an independent risk factor (2-3-fold) for HCC [136]. Insulin resistance with exacerbated production of reactive oxygen species lead to subclinical chronic hepatic inflammation, being a driver of hepatocarcinogenesis $[137,138]$. In addition, primary biliary cholangitis, a rare autoimmune disease, has been shown to predispose for HCC development [139]. Further, hemochromatosis, which causes accumulation of iron in inner organs and thereby their dysfunction has been identified as a risk factor for HCC [140]. Alcohol consumption is a common risk factor of HCC in the Western world [141]. Further risk factors are biotoxins such as aflatoxins, which play a minor role in industrialized countries [142].

\subsection{Current Treatment Options for HCC}

Altogether, HCC is the most frequent malignant form of primary liver cancer (annual incidence $7 / 100,000)$ and is the second leading cause of cancer-related deaths worldwide, accounting for more than 45,000 deaths per year only in Europe [143]. Management of HCC is complex and depends on the tumor extent, patient's comorbidities, and the remaining liver function as most treatments risk exacerbating the underlying disease. HCC treatment includes a multidisciplinary team, consisting of hepatologists, visceral surgeons, and interventional radiologists to achieve the best outcomes. Surgical resection is recommended as a curative treatment in HCC patients with respectable disease in an early stage $[144,145]$. Liver transplantation represents the most definite treatment option when patients meet the Milan criteria [146]. The Milan criteria describe the extent of the disease and take into account quantity, size, gross vascular invasion, and extrahepatic manifestations of the tumors [147]. Percutaneous local ablation by radiofrequency [148] or microwaves as well as transarterial chemoembolization [149] and proton beam are treatment options at an early or intermediate advanced state [148]. However, at advanced stages, systemic treatment remains the last therapeutic option. Sorafenib is a small-molecule multikinase inhibitor that inhibits VEGFR1-3, PDGF receptor- $\beta$, and Raf family kinases [150]. It was the first approved drug for first-line systemic treatment, prolonging the median survival of 10.7 months in the sorafenib group vs. 7.9 months in the placebo group [151]. Recently, the multikinase inhibitors levantinib [152] and regorafenib [153] were approved as first- and second-line therapy options after sorafenib treatment, respectively. In 2017 and 2018, the immune checkpoint inhibitors nivolumab [154] and pembrolizumab [155], both PD1-inhibitors, have emerged as second-line therapy, respectively. Recently, ramucirumab, an antiangiogenic VEGFR2 antagonist, expanded the field of second-line therapies and was approved for patients with high serums levels of $\alpha$-fetoprotein $(\geq 400 \mathrm{ng} / \mathrm{mL})$ and previous treatment with sorafenib [156]. Despite significant progress having been made in systemic therapy of HCC, prognosis is still limited (median survival < 1 year) [130]. 
Thus, novel therapeutic approaches which are synergistic to established regimes are urgently needed to improve outcomes.

\subsection{Macrophages Are Key Players in HCC Progression}

The tumor biology of HCC can only be fully conceived when considering also the tumor surrounding tissue: the TME [157]. The extracellular matrix represents the non-cellular component of the TME. It contains polysaccharides (e.g., glycosaminoglycan hyaluronic acid) and proteoglycans which are found at high levels in the TME of HCC [158]. Beside the tumor cells, the cellular component of the TME consists of a variety of parenchymal and non-parenchymal cells, including tumor-associated fibroblasts, endothelial cells, adipocytes, and cells of the immune system. The sum of immune cells inside the TME build the tumor immune microenvironment (TIME). There is mounting evidence that the TME and especially the TIME play crucial roles in the development and progression of HCC [157].

KCs and MoMFs play pivotal roles in the development and growth of HCC in the TIME [78]. KCs are liver-resident macrophages, self-renewing, and non-migratory phagocytes and serve as sentinels for liver homeostasis [159]. Upon liver injury, they become activated and excrete inflammatory cytokines (e.g., TNF- $\alpha$ ) and chemokines (e.g., CCL2), attracting numerous pro-inflammatory Ly-6C ${ }^{+}$ monocytes from the bone marrow [78]. These inflammatory MoMFs activate HSCs and drive their trans-differentiation into activated myofibroblasts [160]. The latter are the major collagen-producing cells, and a main source of both profibrotic and proangiogenic cytokines (e.g., TGF- $\beta 1$ and PDGF) in liver fibrogenesis [161].

Since both KCs and MoMFs possess high plasticity, TAMs are thought to derive from these two distinct macrophage populations [78]. As high numbers of TAMs are regularly observed in resections or explants of patients with HCC, they are supposed to promote development and progress of HCC [162]. This assumption is further supported by the fact that TAM numbers correlate with HCC progression and poor survival [163]. TAMs were also found to express PD-L1, which suppresses anti-tumoral CTL responses [164,165] (Figure 3). Furthermore, TAMs provide soluble factors that favor tumor cell proliferation, inhibit apoptosis of cancer cells and promote angiogenesis [157], and induce the conversion of fibroblasts towards cancer-associated fibroblasts (CAFs) [166], which in turn via modulation of the ECM and the production of numerous immunomodulatory soluble mediators shape the TME [167]. TAMs retain their plasticity and can switch their phenotype towards "antifibrotic" and putatively "anti-tumor" macrophages [168]. This phenotype is characterized by low expression of Ly-6C in mice and high expression of anti-inflammatory mediators (e.g., HGF and IL-10) and matrix (degrading) metalloproteinases (e.g., MMP-9, MMP-12, and MMP-13) [169]. Thus, a drug-induced phenotypic switch towards "good-natured" macrophages is an appealing concept and has gained increasing attention in basic and drug translational research in the last decade. 


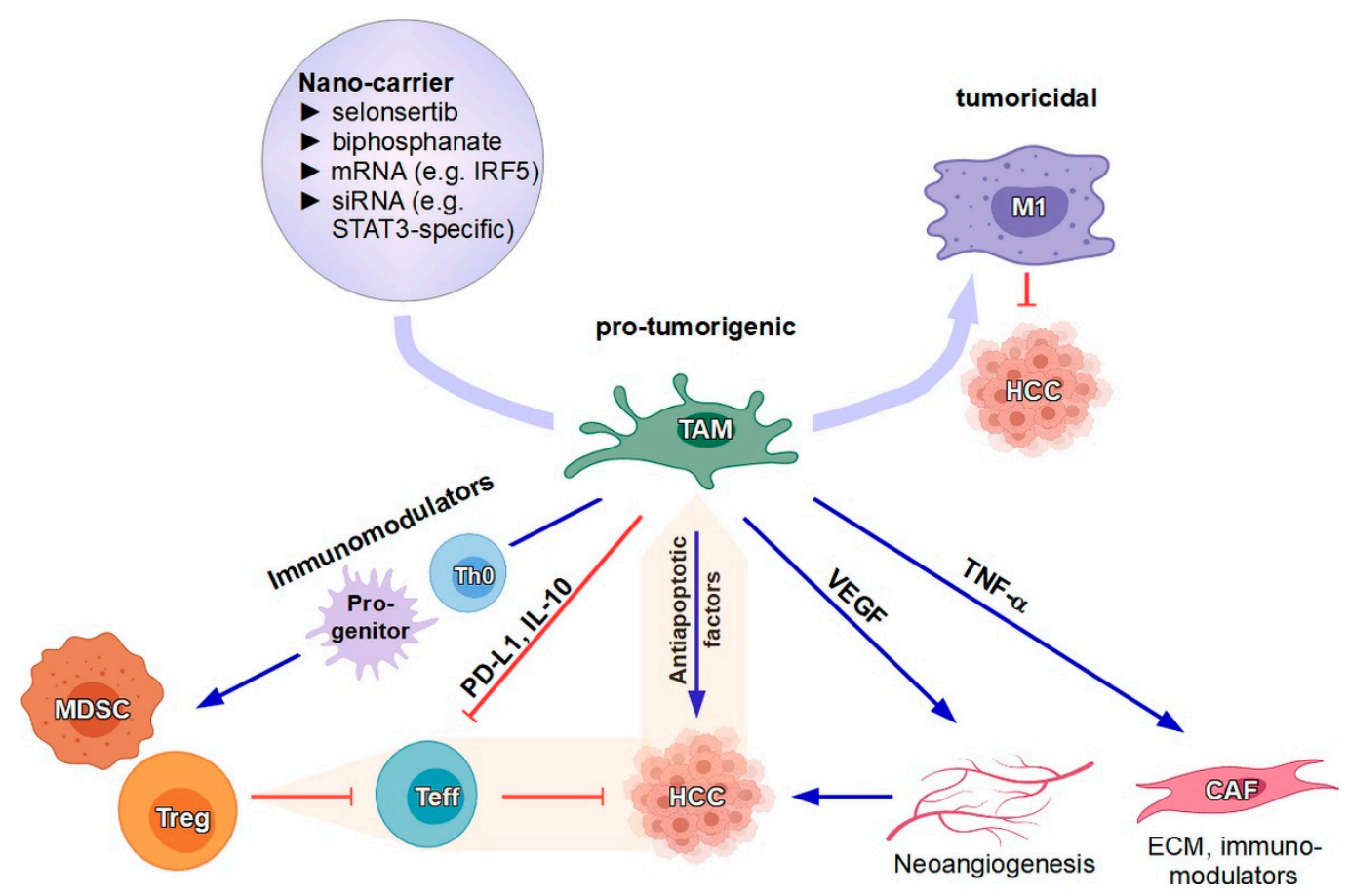

Figure 3. Hepatocellular carcinoma (HCC) generates numerous immunomodulatory soluble factors which govern the differentiation of infiltrating macrophages towards M2-like tumor-associated macrophages (TAMs) and the induction/expansion of myeloid-derived suppressor cells (MDSCs) and Treg and inhibit T effector cells (Teff). TAMs exert overall pro-tumorigenic effects by producing soluble mediators which support tumor progression directly and indirectly via VEGF-dependent neoangiogenesis, and induction of cancer-associated fibroblasts (CAFs) that also shape the tumor microenvironment (TME). Similar to HCC, TAMs also inhibit infiltrating Teff and promote MDSCs as well as Treg that also inhibit antitumor responses. Due to their crucial role, reprogramming of TAMs towards M1-like macrophages with tumoricidal activity has been evaluated using nanocarriers that deliver nucleic acid-based therapeutics. Moreover, drugs like selonsertib and bisphosphonate, previously shown to repolarize TAMs, are suitable payloads for TAM-targeting nanocarriers, thereby minimizing cytotoxicity.

\subsection{Targeting of TAMs with NPs for Tumor Therapy}

TAMs express rather a tolerogenic phenotype and thus provoke tumor progression and metastasis [170]. In this sense, it has been of great interest to induce TAM polarization towards a proinflammatory state that can elicit immune responses and tumor regression. TAMs can be targeted by nanoparticle-based drug delivery [13]. Nanocarriers are ideal for this purpose for three reasons. First, TAMs as phagocytes have a high scavenging capacity and efficiently engulf foreign particles, including NPs, by passive targeting [171]. Second, after intravenous injection in mice, the majority of nanocarriers like nanohydrogel particles (approximately $50 \mathrm{~nm} \varnothing$ ) [172,173], hard-shell microbubbles (approximately $2 \mathrm{~nm} \varnothing$ ), liposomes (approximately $2 \mathrm{~nm} \varnothing$ ), and polymers (approximately $10 \mathrm{~nm} \varnothing$ ) [90] accumulate efficiently in the liver and arrive in close proximity to liver macrophages. Third, cell-specific active targeting of NP may enhance their uptake by TAMs. TAMs express CD206, which efficiently binds mannose residues at high extents [174]. Mannose-functionalized nanohydrogel particles (ManNPs) loaded with colony stimulating factor (CSF)-1 receptor small interfering RNA (siRNA) demonstrated a robust knockdown of CSF-1 in CD206 overexpressing primary macrophages in vitro, while CD206-negative macrophages were not affected [173]. Thus, ManNPs represent a promising platform for cell type-specific delivery of siRNA to profibrotic macrophages which share characteristics with TAMs. 
A recent study reported the use of polymeric NPs engineered to deliver mRNA-encoded modulatory proteins. Delivery of mRNA species that encoded interferon regulatory factor (IRF) 5 and IKB kinase (IKK) $\beta$, which activates IRF5 [175], was intended to cause a shift of TAMs towards a pro-inflammatory and cytotoxic M1-like phenotype [176]. In line, in in vivo models of advanced-stage ovarian cancer, metastatic melanoma, and glioblastoma, a reduced density of TAM in tumor lesions and concomitantly a marked increase in inflammatory myeloid cells with M1-type transcriptional profiles was observed. Even though this approach has not been tested for hepatic macrophages, the efficacy of this strategy proves that NP may be employed, e.g., for tumor therapy to repolarize macrophages with regulatory function to exert pro-inflammatory effects.

siRNA are double-stranded noncoding RNA oligos (20-25 base pairs) that sequence-specifically hybridize with their target mRNA to induce its degradation and to thereby diminish its half-life and translation [177]. RNA inference by siRNA allows transient silencing of virtually any gene, offering a huge value for therapeutic applications. It can be envisioned that NPs loaded with siRNA which target relevant pathways of TAMs may induce a phenotype switch or apoptosis of TAMs [178]. Cell type-specific delivery of therapeutic siRNA with functionalized carriers (e.g., ManNPs) to TAMs could improve efficacy and could avoid off-target effects in non-targeted cell types. For example, in a human tumor xenograft model, lipid NP loaded with siRNA specific for the M2-promoting transcription factor STAT (signal transducer and activator of transcription) 3 repolarized TAMs towards a M1-like immunophenotype and therefore reverted their pro-tumoral effects [179].

Hepatic macrophages and hepatocytes share a set of intracellular inflammatory signaling pathways (e.g., NF-KB, apoptosis signal-regulating kinase 1 (ASK-1), c-Jun N-terminal kinase, and p38) [180]. It is conceivable that specific inhibitors of inflammatory signaling like the ASK-1 inhibitor selonsertib have effects not only on hepatocyte metabolism but also on macrophage activation [78,181]. Encapsulation of this small-molecule drug in NPs could enhance the effect on TAMs. Further, bisphosphonates are anti-resorptive agents used in the clinic for osteoporosis [182] and complications of bone metastasis [183]. There is evidence that bisphosphonates also have an effect on the phenotype of macrophages, shifting it from pro-tumoral to tumoricidal [184]. Since bisphosphonates are largely excreted by the urinary tract und rapidly bind to bones upon intravenous administration, their encapsulation by biocompatible carriers could be of interest to target TAMs.

Altogether, TAMs are immunosuppressive cells in the TIME of HCC and were identified as a crucial cell population to fuel tumor development and growth. Therapeutic targeting of TAMs seems promising and might be achieved either by small-molecule or siRNA-based drugs encapsulated in NPs.

\section{Conclusions}

Liver NPCs are equipped with numerous receptors to internalize material and, by default, to confer tolerance [76]. Consequently, liver NPCs also strongly bind systemically applied NPs which, on the one hand, can be exploited for direct targeting of KCs or LSECs, e.g., to induce antigen-specific tolerance [57], but, on the other hand, constitutes an unwanted outcome in the case of NPs applied to evoke immune responses in secondary lymphoid organs. With regard to the latter, it is not clear yet whether LSECs and KCs that internalize nano-vaccines aimed to induce antitumor T cell responses may promote tumor antigen-specific tolerance as depicted in Figure 4 and therefore to counteract vaccine-induced adaptive immune reactions. As a perspective, nano-vaccines may be designed to co-deliver adjuvants that activate not only APCs in secondary lymphoid organs but also LSECs [185] and KCs [186] to promote the establishment of effector T cell responses throughout the body. However, it needs to be taken into account that hyperactivated liver NPCs, for example, M1-type KCs, may also cause inflammation and tissue damage $[101,187]$. Alternatively, nano-vaccines aimed to induce adaptive immune responses in secondary lymphoid organs may be generated in such a manner that unwanted binding and uptake by liver NPC is largely avoided. For this, nano-vaccines should not be decorated with APC-targeting moieties that are also recognized by surface receptors expressed by either liver immune cell population (e.g., CD206 [34]). In general, cellular interaction of NPs and NP-induced 
alterations of the cellular immunophenotype should be assessed first in vitro, e.g., by using in parallel assays murine liver NPCs and spleen cells, also taking into account that a serum-dependently formed protein corona may strongly alter the targeting properties of NPs [188].

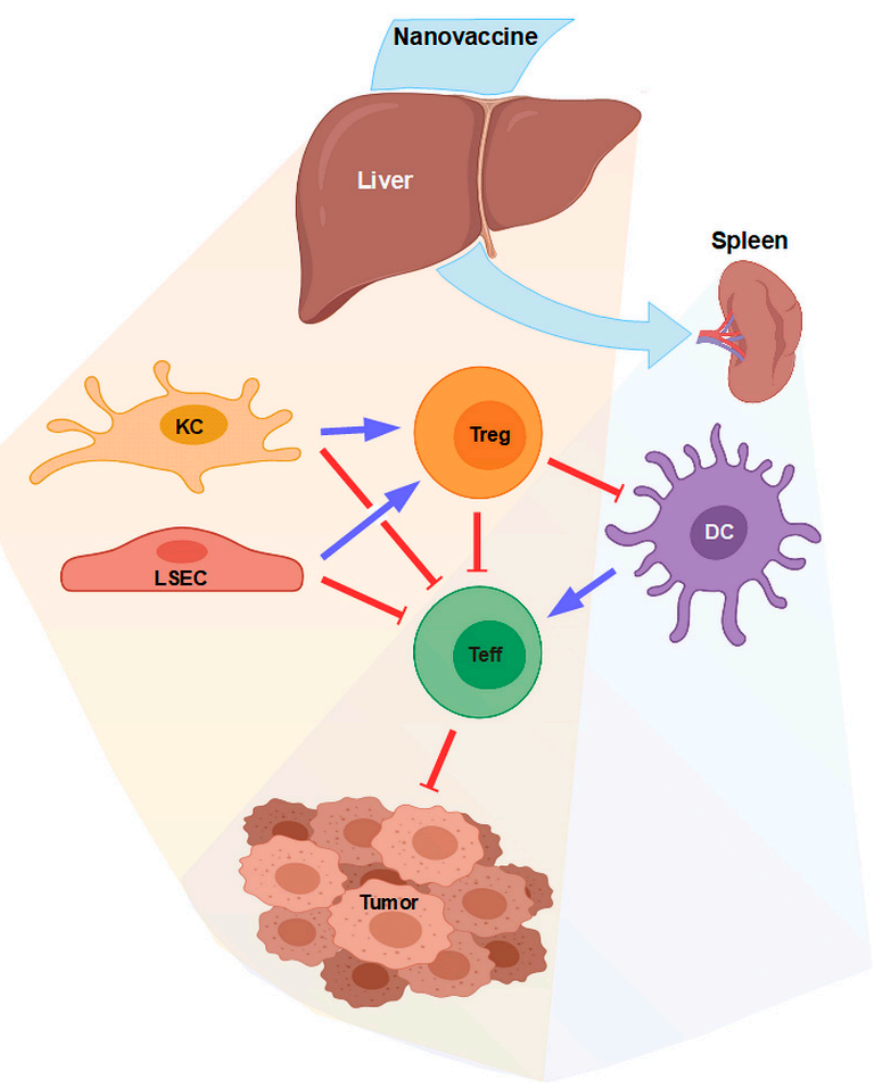

Figure 4. Systemically applied nano-vaccines often accumulate in the liver and reach secondary lymphoid organs only at low extents. In liver, nano-vaccines may be internalized largely by KCs and LSECs, which at default state promote Treg induction and could inhibit tumor-specific T effector cells induced by dendritic cells (DCs) in lymphoid organs. To avoid this outcome, nano-vaccines may either be designed to contain adjuvants that activate KCs/LSECs or to avoid unwanted uptake by liver non-parenchymal cells (NPCs).

Author Contributions: Each author has substantially contributed to drafting this review. M.L.C., S.G. and M.B. conceptualized the review topic. M.L.C., C.M.-M., L.K., C.K., and M.B. wrote the manuscript draft and M.B. revised it. All authors have read and agreed to the published version of the manuscript.

Funding: This work was funded by the Deutsche Forschungsgemeinschaft grant number SFB1066.

Conflicts of Interest: The authors declare no conflict of interest.

$\begin{array}{ll}\text { Abbreviations } & \\ \text { APC } & \text { antigen presenting cell } \\ \text { APF } & \text { 4-aminophenyl- } \beta \text {-L-fucopyranoside } \\ \text { APM } & \text { 4-aminophenyl- } \alpha \text {-D-mannopyranoside } \\ \text { ASK-1 } & \text { apoptosis signal-regulating kinase } 1 \\ \text { CAF } & \text { cancer-associated fibroblasts } \\ \text { CLR } & \text { C-type lectin receptor } \\ \text { CCL } & \text { chemokine (C-C motif) ligand } \\ \text { CLR } & \text { C-type lectin receptor }\end{array}$


CR

CSF-1

CTL

CXCL

DC

DC-SIGNR

FcR

HCC

HSC

ICAM

IFN

IL

IRF

$\mathrm{KC}$

L-SIGN

LSEC

LYVE-1

M6P

ManNP

MARCO

MDSC

MHC

MMP

MoMF

NAFLD

NF- $\kappa B$

NKT

NOD

NPC

NP

PDGF

PD-L1

PPAR

RBP

PRR

RIG

RLR

SCAR

siRNA

STAT

TAM

TEM

TIME

TGF

Th

TLR

Treg

VAP

VCAM

VEGFR

VWF complement receptor

colony stimulating factor 1

cytotoxic T lymphocyte

chemokine (C-X-C motif) ligand

dendritic cell

DC-SIGN-related protein

Fc receptor

hepatocellular carcinoma

hepatic stellate cell

intercellular adhesion molecule

interferon

interleukin

interferon regulatory factor

Kupffer cell

liver/lymph node-specific intercellular adhesion molecule

[ICAM]-3 grabbing non-integrin

liver sinusoidal endothelial cells

lymphatic vessel endothelial receptor 1

mannose-6-phosphat

mannose-functionalized nanohydrogel particles

macrophage receptor with collagenous structure

myeloid-derived suppressor cell

major histocompatibility complex

matrix metalloproteinase

monocyte-derived macrophages

non-alcoholic fatty liver disease

nuclear factor kappa B

natural killer $\mathrm{T}$ cell

nucleotide binding oligomerization domain containing

non-parenchymal cell

nanoparticle

platelet-derived growth factor

programmed death-ligand 1

peroxisome proliferator activated receptor

retinol binding protein

pathogen-associated molecular pattern

retinoic acid-inducible gene

RIG-like receptor

scavenger receptor

small interfering RNA

signal transducer and activator of transcription

tumor-associated macrophage

tumor microenvironment

tumor immune microenvironment

tumor growth factor

$\mathrm{T}$ helper cell

Toll-like receptor

regulatory $\mathrm{T}$ cell

vascular adhesion protein

vascular cell adhesion protein

vascular endothelial growth factor

von-Willebrand-Factor 


\section{References}

1. Lungu, I.I.; Grumezescu, A.M.; Volceanov, A.; Andronescu, E. Nanobiomaterials Used in Cancer Therapy: An Up-To-Date Overview. Molecules 2019, 24, 3547. [CrossRef] [PubMed]

2. Kranz, L.M.; Diken, M.; Haas, H.; Kreiter, S.; Loquai, C.; Reuter, K.C.; Meng, M.; Fritz, D.; Vascotto, F.; Hefesha, H.; et al. Systemic RNA delivery to dendritic cells exploits antiviral defence for cancer immunotherapy. Nature 2016, 534, 396-401. [CrossRef] [PubMed]

3. Baetke, S.C.; Lammers, T.; Kiessling, F. Applications of nanoparticles for diagnosis and therapy of cancer. Br. J. Radiol. 2015, 88, 20150207. [CrossRef] [PubMed]

4. $\quad$ Lee, A.R.; Nam, K.; Lee, B.J.; Lee, S.W.; Baek, S.M.; Bang, J.S.; Choi, S.K.; Park, S.J.; Kim, T.H.; Jeong, K.S.; et al. Hepatic Cellular Distribution of Silica Nanoparticles by Surface Energy Modification. Int. J. Mol. Sci. 2019, 20, 3812. [CrossRef] [PubMed]

5. Vijayan, V.; Mohapatra, A.; Uthaman, S.; Park, I.K. Recent Advances in Nanovaccines Using Biomimetic Immunomodulatory Materials. Pharmaceutics 2019, 11, 534. [CrossRef] [PubMed]

6. Li, S.Y.; Liu, Y.; Xu, C.F.; Shen, S.; Sun, R.; Du, X.J.; Xia, J.X.; Zhu, Y.H.; Wang, J. Restoring anti-tumor functions of $\mathrm{T}$ cells via nanoparticle-mediated immune checkpoint modulation. J. Control. Release 2016, 231, 17-28. [CrossRef]

7. Schmetterer, K.G.; Pickl, W.F. The IL-10/STAT3 axis: Contributions to immune tolerance by thymus and peripherally derived regulatory T-cells. Eur. J. Immunol. 2017, 47, 1256-1265. [CrossRef]

8. Paulis, L.E.; Mandal, S.; Kreutz, M.; Figdor, C.G. Dendritic cell-based nanovaccines for cancer immunotherapy. Curr. Opin. Immunol. 2013, 25, 389-395. [CrossRef]

9. Liu, J.; Wang, J.; Zhu, Q.; Yu, C.; Yin, J.; Zheng, L.; Li, A. Mannosylated PEGylated-Polyethyleneimine as Efficient CpG Oligodeoxynucleotide Carriers for Efficient Dendritic Cell Targeting Delivery and Activation. J. Biomed. Nanotechnol. 2019, 15, 1454-1467. [CrossRef]

10. Souto, E.B.; Ribeiro, A.F.; Ferreira, M.I.; Teixeira, M.C.; Shimojo, A.A.M.; Soriano, J.L.; Naveros, B.C.; Durazzo, A.; Lucarini, M.; Souto, S.B.; et al. New Nanotechnologies for the Treatment and Repair of Skin Burns Infections. Int. J. Mol. Sci. 2020, 21, 393. [CrossRef]

11. Meng, H.; Leong, W.; Leong, K.W.; Chen, C.; Zhao, Y. Walking the line: The fate of nanomaterials at biological barriers. Biomaterials 2018, 174, 41-53. [CrossRef] [PubMed]

12. Surendran, S.P.; Thomas, R.G.; Moon, M.J.; Jeong, Y.Y. Nanoparticles for the treatment of liver fibrosis. Int. J. Nanomed. 2017, 12, 6997-7006. [CrossRef] [PubMed]

13. Yong, S.B.; Chung, J.Y.; Song, Y.; Kim, J.; Ra, S.; Kim, Y.H. Non-viral nano-immunotherapeutics targeting tumor microenvironmental immune cells. Biomaterials 2019, 219, 119401. [CrossRef] [PubMed]

14. Zheng, M.; Tian, Z. Liver-Mediated Adaptive Immune Tolerance. Front. Immunol. 2019, 10, 2525. [CrossRef] [PubMed]

15. Dou, L.; Ono, Y.; Chen, Y.F.; Thomson, A.W.; Chen, X.P. Hepatic Dendritic Cells, the Tolerogenic Liver Environment, and Liver Disease. Semin. Liver Dis. 2018, 38, 170-180. [CrossRef] [PubMed]

16. Samuelsson, E.; Shen, H.; Blanco, E.; Ferrari, M.; Wolfram, J. Contribution of Kupffer cells to liposome accumulation in the liver. Colloids Surf. B Biointerfaces 2017, 158, 356-362. [CrossRef] [PubMed]

17. Park, J.K.; Utsumi, T.; Seo, Y.E.; Deng, Y.; Satoh, A.; Saltzman, W.M.; Iwakiri, Y. Cellular distribution of injected PLGA-nanoparticles in the liver. Nanomed. Nanotechnol. Biol. Med. 2016, 12, 1365-1374. [CrossRef]

18. Poisson, J.; Lemoinne, S.; Boulanger, C.; Durand, F.; Moreau, R.; Valla, D.; Rautou, P.E. Liver sinusoidal endothelial cells: Physiology and role in liver diseases. J. Hepatol. 2017, 66, 212-227. [CrossRef]

19. Karrar, A.; Broome, U.; Uzunel, M.; Qureshi, A.R.; Sumitran-Holgersson, S. Human liver sinusoidal endothelial cells induce apoptosis in activated T cells: A role in tolerance induction. Gut 2007, 56, $243-252$. [CrossRef]

20. Sorensen, K.K.; Simon-Santamaria, J.; McCuskey, R.S.; Smedsrod, B. Liver Sinusoidal Endothelial Cells. Compr. Physiol. 2015, 5, 1751-1774. [CrossRef]

21. Ganesan, L.P.; Kim, J.; Wu, Y.; Mohanty, S.; Phillips, G.S.; Birmingham, D.J.; Robinson, J.M.; Anderson, C.L. FcgammaRIIb on liver sinusoidal endothelium clears small immune complexes. J. Immunol. 2012, 189, 4981-4988. [CrossRef] [PubMed] 
22. Elvevold, K.; Simon-Santamaria, J.; Hasvold, H.; McCourt, P.; Smedsrod, B.; Sorensen, K.K. Liver sinusoidal endothelial cells depend on mannose receptor-mediated recruitment of lysosomal enzymes for normal degradation capacity. Hepatology 2008, 48, 2007-2015. [CrossRef] [PubMed]

23. DeLeve, L.D.; Maretti-Mira, A.C. Liver Sinusoidal Endothelial Cell: An Update. Semin. Liver Dis. 2017, 37, 377-387. [CrossRef] [PubMed]

24. Xie, G.; Wang, L.; Wang, X.; Wang, L.; DeLeve, L.D. Isolation of periportal, midlobular, and centrilobular rat liver sinusoidal endothelial cells enables study of zonated drug toxicity. Am. J. Physiol. Gastrointest. Liver Physiol. 2010, 299, G1204-G1210. [CrossRef] [PubMed]

25. Lertkiatmongkol, P.; Liao, D.; Mei, H.; Hu, Y.; Newman, P.J. Endothelial functions of platelet/endothelial cell adhesion molecule-1 (CD31). Curr. Opin. Hematol. 2016, 23, 253-259. [CrossRef]

26. Dingle, A.M.; Yap, K.K.; Gerrand, Y.W.; Taylor, C.J.; Keramidaris, E.; Lokmic, Z.; Kong, A.M.; Peters, H.L.; Morrison, W.A.; Mitchell, G.M. Characterization of isolated liver sinusoidal endothelial cells for liver bioengineering. Angiogenesis 2018, 21, 581-597. [CrossRef]

27. Simon-Santamaria, J.; Malovic, I.; Warren, A.; Oteiza, A.; Le Couteur, D.; Smedsrod, B.; McCourt, P.; Sorensen, K.K. Age-related changes in scavenger receptor-mediated endocytosis in rat liver sinusoidal endothelial cells. J. Gerontol. A Biol. Sci. Med. Sci. 2010, 65, 951-960. [CrossRef]

28. Meyer, J.; Gonelle-Gispert, C.; Morel, P.; Buhler, L. Methods for Isolation and Purification of Murine Liver Sinusoidal Endothelial Cells: A Systematic Review. PLoS ONE 2016, 11, e0151945. [CrossRef]

29. Busold, S.; Nagy, N.A.; Tas, S.W.; van Ree, R.; de Jong, E.C.; Geijtenbeek, T.B.H. Various Tastes of Sugar: The Potential of Glycosylation in Targeting and Modulating Human Immunity via C-Type Lectin Receptors. Front. Immunol. 2020, 11, 134. [CrossRef]

30. Mnich, M.E.; van Dalen, R.; van Sorge, N.M. C-Type Lectin Receptors in Host Defense Against Bacterial Pathogens. Front. Cell Infect. Microbiol. 2020, 10, 309. [CrossRef]

31. Drouin, M.; Saenz, J.; Chiffoleau, E. C-Type Lectin-Like Receptors: Head or Tail in Cell Death Immunity. Front. Immunol. 2020, 11, 251. [CrossRef] [PubMed]

32. Nonaka, M.; Ma, B.Y.; Murai, R.; Nakamura, N.; Baba, M.; Kawasaki, N.; Hodohara, K.; Asano, S.; Kawasaki, T. Glycosylation-dependent interactions of C-type lectin DC-SIGN with colorectal tumor-associated Lewis glycans impair the function and differentiation of monocyte-derived dendritic cells. J. Immunol. 2008, 180, 3347-3356. [CrossRef] [PubMed]

33. Del Fresno, C.; Iborra, S.; Saz-Leal, P.; Martínez-López, M.; Sancho, D. Flexible Signaling of Myeloid C-Type Lectin Receptors in Immunity and Inflammation. Front. Immunol. 2018, 9, 804. [CrossRef] [PubMed]

34. Pustylnikov, S.; Sagar, D.; Jain, P.; Khan, Z.K. Targeting the C-type lectins-mediated host-pathogen interactions with dextran. J. Pharm. Pharm. Sci. 2014, 17,371-392. [CrossRef]

35. Zhang, F.; Ren, S.; Zuo, Y. DC-SIGN, DC-SIGNR and LSECtin: C-type lectins for infection. Int. Rev. Immunol. 2014, 33, 54-66. [CrossRef]

36. Van den Berg, L.M.; Gringhuis, S.I.; Geijtenbeek, T.B. An evolutionary perspective on C-type lectins in infection and immunity. Ann. N. Y. Acad. Sci. 2012, 1253, 149-158. [CrossRef]

37. Yang, Z.; Li, Q.; Wang, X.; Jiang, X.; Zhao, D.; Lin, X.; He, F.; Tang, L. C-type lectin receptor LSECtin-mediated apoptotic cell clearance by macrophages directs intestinal repair in experimental colitis. Proc. Natl. Acad. Sci. USA 2018, 115, 11054-11059. [CrossRef]

38. Domínguez-Soto, A.; Aragoneses-Fenoll, L.; Gómez-Aguado, F.; Corcuera, M.T.; Clária, J.; García-Monzón, C.; Bustos, M.; Corbí, A.L. The pathogen receptor liver and lymph node sinusoidal endotelial cell C-type lectin is expressed in human Kupffer cells and regulated by PU.1. Hepatology 2009, 49, 287-296. [CrossRef]

39. Malovic, I.; Sorensen, K.K.; Elvevold, K.H.; Nedredal, G.I.; Paulsen, S.; Erofeev, A.V.; Smedsrod, B.H.; McCourt, P.A. The mannose receptor on murine liver sinusoidal endothelial cells is the main denatured collagen clearance receptor. Hepatology 2007, 45, 1454-1461. [CrossRef]

40. Cormier, E.G.; Durso, R.J.; Tsamis, F.; Boussemart, L.; Manix, C.; Olson, W.C.; Gardner, J.P.; Dragic, T. L-SIGN (CD209L) and DC-SIGN (CD209) mediate transinfection of liver cells by hepatitis C virus. Proc. Natl. Acad. Sci. USA 2004, 101, 14067-14072. [CrossRef]

41. Tanigaki, K.; Sundgren, N.; Khera, A.; Vongpatanasin, W.; Mineo, C.; Shaul, P.W. Fcgamma receptors and ligands and cardiovascular disease. Circ. Res. 2015, 116, 368-384. [CrossRef] [PubMed] 
42. Wu, J.; Meng, Z.; Jiang, M.; Zhang, E.; Trippler, M.; Broering, R.; Bucchi, A.; Krux, F.; Dittmer, U.; Yang, D.; et al. Toll-like receptor-induced innate immune responses in non-parenchymal liver cells are cell type-specific. Immunology 2010, 129, 363-374. [CrossRef] [PubMed]

43. Huang, S.; Wu, J.; Gao, X.; Zou, S.; Chen, L.; Yang, X.; Sun, C.; Du, Y.; Zhu, B.; Li, J.; et al. LSECs express functional NOD1 receptors: A role for NOD1 in LSEC maturation-induced T cell immunity in vitro. Mol. Immunol. 2018, 101, 167-175. [CrossRef] [PubMed]

44. Kruse, N.; Neumann, K.; Schrage, A.; Derkow, K.; Schott, E.; Erben, U.; Kuhl, A.; Loddenkemper, C.; Zeitz, M.; Hamann, A.; et al. Priming of CD4+ T cells by liver sinusoidal endothelial cells induces CD25low forkhead box protein 3- regulatory T cells suppressing autoimmune hepatitis. Hepatology 2009, 50, 1904-1913. [CrossRef] [PubMed]

45. Rubinstein, D.; Roska, A.K.; Lipsky, P.E. Liver sinusoidal lining cells express class II major histocompatibility antigens but are poor stimulators of fresh allogeneic T lymphocytes. J. Immunol. 1986, 137, 1803-1810.

46. Damle, N.K.; Aruffo, A. Vascular cell adhesion molecule 1 induces T-cell antigen receptor-dependent activation of CD4+T lymphocytes. Proc. Natl. Acad. Sci. USA 1991, 88, 6403-6407. [CrossRef]

47. Lalor, P.F.; Edwards, S.; McNab, G.; Salmi, M.; Jalkanen, S.; Adams, D.H. Vascular adhesion protein-1 mediates adhesion and transmigration of lymphocytes on human hepatic endothelial cells. J. Immunol. 2002, 169, 983-992. [CrossRef]

48. Slawek, A.; Maj, T.; Chelmonska-Soyta, A. CD40, CD80, and CD86 costimulatory molecules are differentially expressed on murine splenic antigen-presenting cells during the pre-implantation period of pregnancy, and they modulate regulatory T-cell abundance, peripheral cytokine response, and pregnancy outcome. Am. J. Reprod. Immunol. 2013, 70, 116-126. [CrossRef]

49. Knolle, P.A.; Wohlleber, D. Immunological functions of liver sinusoidal endothelial cells. Cell. Mol. Immunol. 2016, 13, 347-353. [CrossRef]

50. Berg, M.; Wingender, G.; Djandji, D.; Hegenbarth, S.; Momburg, F.; Hammerling, G.; Limmer, A.; Knolle, P. Cross-presentation of antigens from apoptotic tumor cells by liver sinusoidal endothelial cells leads to tumor-specific CD8+ T cell tolerance. Eur. J. Immunol. 2006, 36, 2960-2970. [CrossRef]

51. Blander, J.M. Regulation of the Cell Biology of Antigen Cross-Presentation. Annu. Rev. Immunol. 2018, 36, 717-753. [CrossRef]

52. Diehl, L.; Schurich, A.; Grochtmann, R.; Hegenbarth, S.; Chen, L.; Knolle, P.A. Tolerogenic maturation of liver sinusoidal endothelial cells promotes B7-homolog 1-dependent CD8+ T cell tolerance. Hepatology 2008, 47, 296-305. [CrossRef] [PubMed]

53. Knolle, P.A.; Germann, T.; Treichel, U.; Uhrig, A.; Schmitt, E.; Hegenbarth, S.; Lohse, A.W.; Gerken, G. Endotoxin down-regulates $\mathrm{T}$ cell activation by antigen-presenting liver sinusoidal endothelial cells. J. Immunol. 1999, 162, 1401-1407. [PubMed]

54. Carambia, A.; Frenzel, C.; Bruns, O.T.; Schwinge, D.; Reimer, R.; Hohenberg, H.; Huber, S.; Tiegs, G.; Schramm, C.; Lohse, A.W.; et al. Inhibition of inflammatory CD4 T cell activity by murine liver sinusoidal endothelial cells. J. Hepatol. 2013, 58, 112-118. [CrossRef] [PubMed]

55. Neumann, K.; Rudolph, C.; Neumann, C.; Janke, M.; Amsen, D.; Scheffold, A. Liver sinusoidal endothelial cells induce immunosuppressive IL-10-producing Th1 cells via the Notch pathway. Eur. J. Immunol. 2015, 45, 2008-2016. [CrossRef]

56. Liu, J.; Jiang, M.; Ma, Z.; Dietze, K.K.; Zelinskyy, G.; Yang, D.; Dittmer, U.; Schlaak, J.F.; Roggendorf, M.; $\mathrm{Lu}, \mathrm{M}$. TLR1/2 ligand-stimulated mouse liver endothelial cells secrete IL-12 and trigger CD8+ T cell immunity in vitro. J. Immunol. 2013, 191, 6178-6190. [CrossRef]

57. Liu, Q.; Wang, X.; Liu, X.; Kumar, S.; Gochman, G.; Ji, Y.; Liao, Y.P.; Chang, C.H.; Situ, W.; Lu, J.; et al. Use of Polymeric Nanoparticle Platform Targeting the Liver To Induce Treg-Mediated Antigen-Specific Immune Tolerance in a Pulmonary Allergen Sensitization Model. ACS Nano 2019, 13, 4778-4794. [CrossRef]

58. Arosio, D.; Chiodo, F.; Reina, J.J.; Marelli, M.; Penades, S.; van Kooyk, Y.; Garcia-Vallejo, J.J.; Bernardi, A. Effective targeting of DC-SIGN by alpha-fucosylamide functionalized gold nanoparticles. Bioconjug. Chem. 2014, 25, 2244-2251. [CrossRef]

59. Toth, C.A.; Thomas, P. Liver endocytosis and Kupffer cells. Hepatology 1992, 16, 255-266. [CrossRef]

60. Ishikawa, T.; Yokoyama, H.; Matsuura, T.; Fujiwara, Y. Fc gamma RIIb expression levels in human liver sinusoidal endothelial cells during progression of non-alcoholic fatty liver disease. PLoS ONE 2019, 14, e0211543. [CrossRef] 
61. Jenne, C.N.; Kubes, P. Immune surveillance by the liver. Nat. Immunol. 2013, 14, 996-1006. [CrossRef]

62. Bonnardel, J.; T’Jonck, W.; Gaublomme, D.; Browaeys, R.; Scott, C.L.; Martens, L.; Vanneste, B.; De Prijck, S.; Nedospasov, S.A.; Kremer, A.; et al. Stellate Cells, Hepatocytes, and Endothelial Cells Imprint the Kupffer Cell Identity on Monocytes Colonizing the Liver Macrophage Niche. Immunity 2019, 51, 638-654.e639. [CrossRef] [PubMed]

63. Bilzer, M.; Roggel, F.; Gerbes, A.L. Role of Kupffer cells in host defense and liver disease. Liver Int. 2006, 26, 1175-1186. [CrossRef] [PubMed]

64. MacParland, S.A.; Liu, J.C.; Ma, X.Z.; Innes, B.T.; Bartczak, A.M.; Gage, B.K.; Manuel, J.; Khuu, N.; Echeverri, J.; Linares, I.; et al. Single cell RNA sequencing of human liver reveals distinct intrahepatic macrophage populations. Nat. Commun. 2018, 9, 4383. [CrossRef]

65. Guillot, A.; Tacke, F. Liver Macrophages: Old Dogmas and New Insights. Hepatol. Commun. 2019, 3, 730-743. [CrossRef] [PubMed]

66. Boltjes, A.; Movita, D.; Boonstra, A.; Woltman, A.M. The role of Kupffer cells in hepatitis B and hepatitis C virus infections. J. Hepatol. 2014, 61, 660-671. [CrossRef]

67. Vollmar, B.; Menger, M.D. The hepatic microcirculation: Mechanistic contributions and therapeutic targets in liver injury and repair. Physiol. Rev. 2009, 89, 1269-1339. [CrossRef]

68. Movita, D.; Kreefft, K.; Biesta, P.; van Oudenaren, A.; Leenen, P.J.; Janssen, H.L.; Boonstra, A. Kupffer cells express a unique combination of phenotypic and functional characteristics compared with splenic and peritoneal macrophages. J. Leukoc. Biol. 2012, 92, 723-733. [CrossRef]

69. Van der Heide, D.; Weiskirchen, R.; Bansal, R. Therapeutic Targeting of Hepatic Macrophages for the Treatment of Liver Diseases. Front. Immunol. 2019, 10, 2852. [CrossRef]

70. Chen, G.; Ni, Y.; Nagata, N.; Xu, L.; Zhuge, F.; Nagashimada, M.; Kaneko, S.; Ota, T. Pirfenidone prevents and reverses hepatic insulin resistance and steatohepatitis by polarizing M2 macrophages. Lab. Investig. 2019, 99, 1335-1348. [CrossRef]

71. Huang, H.; Zhang, X.; Zhang, C.; Chen, H.; Ling, Q.; Zheng, S. The time-dependent shift in the hepatic graft and recipient macrophage pool following liver transplantation. Cell. Mol. Immunol. 2020, 17, 412-414. [CrossRef] [PubMed]

72. Su, G.L.; Klein, R.D.; Aminlari, A.; Zhang, H.Y.; Steinstraesser, L.; Alarcon, W.H.; Remick, D.G.; Wang, S.C. Kupffer cell activation by lipopolysaccharide in rats: Role for lipopolysaccharide binding protein and toll-like receptor 4. Hepatology 2000, 31, 932-936. [CrossRef] [PubMed]

73. Hinglais, N.; Kazatchkine, M.D.; Mandet, C.; Appay, M.D.; Bariety, J. Human liver Kupffer cells express CR1, CR3, and CR4 complement receptor antigens. An immunohistochemical study. Lab. Investig. 1989, 61, 509-514. [PubMed]

74. Hughes, D.A.; Fraser, I.P.; Gordon, S. Murine macrophage scavenger receptor: In vivo expression and function as receptor for macrophage adhesion in lymphoid and non-lymphoid organs. Eur. J. Immunol. 1995, 25, 466-473. [CrossRef]

75. Dey, A.; Allen, J.; Hankey-Giblin, P.A. Ontogeny and polarization of macrophages in inflammation: Blood monocytes versus tissue macrophages. Front. Immunol. 2014, 5, 683. [CrossRef] [PubMed]

76. Karimi, M.H.; Geramizadeh, B.; Malek-Hosseini, S.A. Tolerance Induction in Liver. Int. J. Organ Transpl. Med. 2015, 6, 45-54.

77. Heymann, F.; Peusquens, J.; Ludwig-Portugall, I.; Kohlhepp, M.; Ergen, C.; Niemietz, P.; Martin, C.; van Rooijen, N.; Ochando, J.C.; Randolph, G.J.; et al. Liver Inflammation Abrogates Immunological Tolerance Induced by Kupffer Cells. Hepatology 2015, 62, 279-291. [CrossRef]

78. Tacke, F. Targeting hepatic macrophages to treat liver diseases. J. Hepatol. 2017, 66, 1300-1312. [CrossRef]

79. Abdullah, Z.; Knolle, P.A. Liver macrophages in healthy and diseased liver. Pflug. Arch. Eur. J. Physiol. 2017, 469, 553-560. [CrossRef]

80. Knolle, P.; Schlaak, J.; Uhrig, A.; Kempf, P.; Gerken, G.; Btischenfelde, M. Human Kupffer cells secrete IL-10 in response to lipopolysaccharide (LPS) challenge. J. Hepatol. 1995, 22, 226-229. [CrossRef]

81. Doherty, D.G. Immunity, tolerance and autoimmunity in the liver: A comprehensive review. J. Autoimmun. 2016, 66, 60-75. [CrossRef]

82. Doherty, D.G. Antigen-specific immune tolerance in the liver. Nat. Biomed. Eng. 2019, 3, 763-765. [CrossRef] [PubMed] 
83. Jager, J.; Aparicio-Vergara, M.; Aouadi, M. Liver innate immune cells and insulin resistance: The multiple facets of Kupffer cells. J. Intern. Med. 2016, 280, 209-220. [CrossRef] [PubMed]

84. Scott, C.L.; Zheng, F.; De Baetselier, P.; Martens, L.; Saeys, Y.; De Prijck, S.; Lippens, S.; Abels, C.; Schoonooghe, S.; Raes, G.; et al. Bone marrow-derived monocytes give rise to self-renewing and fully differentiated Kupffer cells. Nat. Commun. 2016, 7, 10321. [CrossRef] [PubMed]

85. Colino, C.I.; Lanao, J.M.; Gutierrez-Millan, C. Targeting of Hepatic Macrophages by Therapeutic Nanoparticles. Front. Immunol. 2020, 11, 218. [CrossRef]

86. MacParland, S.A.; Tsoi, K.M.; Ouyang, B.; Ma, X.Z.; Manuel, J.; Fawaz, A.; Ostrowski, M.A.; Alman, B.A.; Zilman, A.; Chan, W.C.W.; et al. Phenotype Determines Nanoparticle Uptake by Human Macrophages from Liver and Blood. ACS Nano 2017, 11, 2428-2443. [CrossRef]

87. Gan, Z.; Lokugamage, M.P.; Hatit, M.Z.C.; Loughrey, D.; Paunovska, K.; Sato, M.; Cristian, A.; Dahlman, J.E. Nanoparticles containing constrained phospholipids deliver mRNA to liver immune cells in vivo without targeting ligands. Bioeng. Transl. Med. 2020. [CrossRef]

88. Saito, E.; Kuo, R.; Kramer, K.R.; Gohel, N.; Giles, D.A.; Moore, B.B.; Miller, S.D.; Shea, L.D. Design of biodegradable nanoparticles to modulate phenotypes of antigen-presenting cells for antigen-specific treatment of autoimmune disease. Biomaterials 2019, 222, 119432. [CrossRef]

89. Hunter, Z.; McCarthy, D.P.; Yap, W.T.; Harp, C.T.; Getts, D.R.; Shea, L.D.; Miller, S.D. A biodegradable nanoparticle platform for the induction of antigen-specific immune tolerance for treatment of autoimmune disease. ACS Nano 2014, 8, 2148-2160. [CrossRef]

90. Ergen, C.; Heymann, F.; Al Rawashdeh, W.; Gremse, F.; Bartneck, M.; Panzer, U.; Pola, R.; Pechar, M.; Storm, G.; Mohr, N.; et al. Targeting distinct myeloid cell populations in vivo using polymers, liposomes and microbubbles. Biomaterials 2017, 114, 106-120. [CrossRef]

91. Melgert, B.N.; Olinga, P.; Van Der Laan, J.M.; Weert, B.; Cho, J.; Schuppan, D.; Groothuis, G.M.; Meijer, D.K.; Poelstra, K. Targeting dexamethasone to Kupffer cells: Effects on liver inflammation and fibrosis in rats. Hepatology 2001, 34, 719-728. [CrossRef] [PubMed]

92. Lai, C.; Li, C.; Luo, X.; Liu, M.; Liu, X.; Hu, L.; Kang, L.; Qiu, Q.; Deng, Y.; Song, Y. Use of Dual-Ligand Modification in Kupffer Cell-Targeted Liposomes to Examine the Contribution of Kupffer Cells to Accelerated Blood Clearance Phenomenon. Mol. Pharm. 2018, 15, 2548-2558. [CrossRef] [PubMed]

93. Lai, C.; Li, C.; Liu, M.; Qiu, Q.; Luo, X.; Liu, X.; Hu, L.; Deng, Y.; Song, Y. Effect of Kupffer cells depletion on ABC phenomenon induced by Kupffer cells-targeted liposomes. Asian J. Pharm. Sci. 2019, 14, 455-464. [CrossRef] [PubMed]

94. Cieslewicz, M.; Tang, J.; Yu, J.L.; Cao, H.; Zaèaljeèski, M.; Motoyama, K.; Lieber, A.; Raines, E.W.; Pun, S.H. Targeted delièery of proapoptotic peptides to tumor-associated macrophages improèes surèièal. Proc. Natl. Acad. Sci. USA 2013, 110, 15919-15924. [CrossRef]

95. Qian, Y.; Qiao, S.; Dai, Y.; Xu, G.; Dai, B.; Lu, L.; Yu, X.; Luo, Q.; Zhang, Z. Molecular-Targeted Immunotherapeutic Strategy for Melanoma via Dual-Targeting Nanoparticles Delivering Small Interfering RNA to Tumor-Associated Macrophages. ACS Nano 2017, 11, 9536-9549. [CrossRef]

96. Kakoschky, B.; Pleli, T.; Schmithals, C.; Zeuzem, S.; Brüne, B.; Vogl, T.J.; Korf, H.W.; Weigert, A.; Piiper, A. Selective targeting of tumor associated macrophages in different tumor models. PLoS ONE 2018, 13, e0193015. [CrossRef]

97. Ju, C.; Tacke, F. Hepatic macrophages in homeostasis and liver diseases: From pathogenesis to novel therapeutic strategies. Cell. Mol. Immunol. 2016, 13, 316-327. [CrossRef]

98. Liu, T.; Li, L.; Fu, C.; Liu, H.; Chen, D.; Tang, F. Pathological mechanisms of liver injury caused by continuous intraperitoneal injection of silica nanoparticles. Biomaterials 2012, 33, 2399-2407. [CrossRef]

99. Bartneck, M.; Ritz, T.; Keul, H.A.; Wambach, M.; Gbureck, U.; Ehling, J.; Lammers, T.; Heymann, F.; Gassler, N.; Lu, T.; et al. Peptide-Functionalized Gold Nanorods Increase Liver Injury in Hepatitis. ACS Nano 2012, 6, 8767-8777. [CrossRef]

100. Yao, Q.; Liu, J.; Zhang, Z.; Li, F.; Zhang, C.; Lai, B.; Xiao, L.; Wang, N. Peroxisome proliferator-activated receptor $\gamma(\operatorname{PPAR} \gamma)$ induces the gene expression of integrin $\alpha(\mathrm{V}) \beta(5)$ to promote macrophage M2 polarization. J. Biol. Chem. 2018, 293, 16572-16582. [CrossRef]

101. Luo, W.; Xu, Q.; Wang, Q.; Wu, H.; Hua, J. Effect of modulation of PPAR- $\gamma$ activity on Kupffer cells M1/M2 polarization in the development of non-alcoholic fatty liver disease. Sci. Rep. 2017, 7, 44612. [CrossRef] [PubMed] 
102. Wake, K. "Sternzellen" in the liver: Perisinusoidal cells with special reference to storage of vitamin A. Am. J. Anat. 1971, 132, 429-461. [CrossRef]

103. Wells, R.G. Cellular Sources of Extracellular Matrix in Hepatic Fibrosis. Clin. Liver Dis. 2008, 12, 759-768. [CrossRef]

104. Devhare, P.B.; Sasaki, R.; Shrivastava, S.; Di Bisceglie, A.M.; Ray, R.; Ray, B. Exosome-Mediated Intercellular Communication between Hepatitis C Virus-Infected Hepatocytes and Hepatic Stellate Cells. J. Virol. $2017,91$. [CrossRef] [PubMed]

105. Puche, J.E.; Saiman, Y.; Friedman, S.L. Hepatic Stellate Cells and Liver Fibrosis. Arch. Patol. Lab. Med. 2013, 3, 1473-1492. [CrossRef]

106. Gandhi, C.R. Hepatic stellate cell activation and pro-fibrogenic signals. J. Hepatol. 2017, 67, $1104-1105$. [CrossRef]

107. Mikula, M.; Proell, V.; Fischer, A.N.M.; Mikulits, W. Activated hepatic stellate cells induce tumor progression of neoplastic hepatocytes in a TGF- $\beta$ dependent fashion. J. Cell. Physiol. 2006, 209, 560-567. [CrossRef]

108. Gandhi, C.R. Chapter 14-Stellate Cells in Hepatic Immunological Tolerance. In Stellate Cells in Health and Disease; Academic Press: Cambridge, MA, USA, 2015; pp. 227-250. [CrossRef]

109. Wang, B.; Trippler, M.; Pei, R.; Lu, M.; Broering, R.; Gerken, G.; Schlaak, J.F. Toll-like receptor activated human and murine hepatic stellate cells are potent regulators of hepatitis $C$ virus replication. J. Hepatol. 2009, 51, 1037-1045. [CrossRef] [PubMed]

110. Watanabe, A.; Hashmi, A.; Gomes, D.A.; Town, T.; Badou, A.; Flavell, R.A.; Mehal, W.Z. Apoptotic hepatocyte DNA inhibits hepatic stellate cell chemotaxis via toll-like receptor 9. Hepatology 2007, 46, 1509-1518. [CrossRef] [PubMed]

111. Bigorgne, A.E.; John, B.; Ebrahimkhani, M.R.; Shimizu-Albergine, M.; Campbell, J.S.; Crispe, I.N. TLR4-dependent secretion by hepatic stellate cells of the neutrophil-chemoattractant CXCL1 mediates liver response to gut microbiota. PLoS ONE 2016, 11, e0151063. [CrossRef] [PubMed]

112. Weiskirchen, R.; Tacke, F. Cellular and molecular functions of hepatic stellate cells in inflammatory responses and liver immunology. Hepatobil Surg. Nutr. 2014, 3, 344-363. [CrossRef]

113. Yu, M.C.; Chen, C.H.; Liang, X.; Wang, L.; Gandhi, C.R.; Fung, J.J.; Lu, L.; Qian, S. Inhibition of T-cell responses by hepatic stellate cells via B7-H1-mediated T-cell apoptosis in mice. Hepatology 2004, 40, 1312-1321. [CrossRef] [PubMed]

114. Zhou, Z.; Xu, M.J.; Cai, Y.; Wang, W.; Jiang, J.X.; Varga, Z.V.; Feng, D.; Pacher, P.; Kunos, G.; Torok, N.J.; et al. Neutrophil-Hepatic Stellate Cell Interactions Promote Fibrosis in Experimental Steatohepatitis. Cell. Mol. Gastroenterol. Hepatol. 2018, 5, 399-413. [CrossRef] [PubMed]

115. Cai, X.; Li, Z.; Zhang, Q.; Qu, Y.; Xu, M.; Wan, X.; Lu, L. CXCL6-EGFR-induced Kupffer cells secrete TGF- $\beta 1$ promoting hepatic stellate cell activation via the SMAD2/BRD4/C-MYC/EZH2 pathway in liver fibrosis. J. Cell. Mol. Med. 2018, 22, 5050-5061. [CrossRef]

116. Benedicto, A.; Herrero, A.; Romayor, I.; Marquez, J.; Smedsrød, B.; Olaso, B.; Arteta, B. Liver sinusoidal endothelial cell ICAM-1 mediated tumor/endothelial crosstalk drives the development of liver metastasis by initiating inflammatory and angiogenic responses. Sci. Rep. 2019, 9, 1-12. [CrossRef]

117. Viñas, O.; Bataller, R.; Sancho-Bru, P.; Ginès, P.; Berenguer, C.; Enrich, C.; Ercilla, G.; Vives, J.; Gallart, T.; Arroyo, V.; et al. Human hepatic stellate cells show features of antigen-presenting cells and stimulate lymphocyte proliferation. Hepatology 2003, 38, 919-929. [CrossRef] [PubMed]

118. Alisi, A.; Romania, P.; Nobili, V.; Locatelli, F.; Fruci, D. Human hepatic stellate cells are liver-resident antigen-presenting cells. Hepatology 2011, 54, 1107. [CrossRef]

119. Winau, F.; Hegasy, G.; Weiskirchen, R.; Weber, S.; Cassan, C.; Sieling, P.A.; Modlin, R.L.; Liblau, R.S.; Gressner, A.M.; Kaufmann, S.H.E. Ito Cells Are Liver-Resident Antigen-Presenting Cells for Activating T Cell Responses. Immunity 2007, 26, 117-129. [CrossRef]

120. Luk, J.M.; Zhang, Q.-S.; Lee, N.P.; Wo, J.Y.; Leung, P.P.; Liu, L.-X.; Hu, M.-Y.; Cheung, K.-F.; Hui, C.-K.; Lau, G.-K.; et al. Hepatic stellate cell-targeted delivery of M6P-HSA-glycyrrhetinic acid attenuates hepatic fibrogenesis in a bile duct ligation rat model. Liver Int. 2007, 27, 548-557. [CrossRef]

121. Sato, Y.; Murase, K.; Kato, J.; Kobune, M.; Sato, T.; Kawano, I.; Takimoto, R.; Takada, K.; Miyanishi, K.; Matsunaga, T.; et al. Resolution of liver cirrhosis using vitamin A-coupled liposomes to deliver siRNA against a collagen-specific chaperone. Nat. Biotechnol. 2008, 26, 431-442. [CrossRef] 
122. Beljaars, L.; Weert, B.; Geerts, A.; Meijer, D.K.F.; Poelstra, K. The preferential homing of a platelet derived growth factor receptor-recognizing macromolecule to fibroblast-like cells in fibrotic tissue. Biochem. Pharmacol. 2003, 66, 1307-1317. [CrossRef]

123. Beljaars, L.; Molema, G.; Schuppan, D.; Geerts, A.; De Bleser, P.J.; Weert, B.; Meijer, D.K.F.; Poelstra, K. Successful targeting to rat hepatic stellate cells using albumin modified with cyclic peptides that recognize the collagen type VI receptor. J. Biol. Chem. 2000, 275, 12743-12751. [CrossRef] [PubMed]

124. Adrian, J.E.; Kamps, J.A.A.M.; Poelstra, K.; Scherphof, G.L.; Meijer, D.K.F.; Kaneda, I. Delivery of viral vectors to hepatic stellate cells in fibrotic livers using HVJ envelopes fused with targeted liposomes. J. Drug Target. 2007, 15, 75-82. [CrossRef]

125. Hu, Q.; Lee, J.-Y.; Luo, Y. Nanoparticles Targeting Hepatic Stellate Cells for the Treatment of Liver Fibrosis. Eng. Sci. 2019, 6, 12-21. [CrossRef]

126. Michalopoulos, G.K.; Bhushan, B. Liver regeneration: Biological and pathological mechanisms and implications. Nat. Rev. Gastroenterol. Hepatol. 2020. [CrossRef] [PubMed]

127. Kitade, M.; Kaji, K.; Yoshiji, H. Relationship between hepatic progenitor cell-mediated liver regeneration and non-parenchymal cells. Hepatol. Res. 2016, 46, 1187-1193. [CrossRef] [PubMed]

128. Tummala, K.S.; Brandt, M.; Teijeiro, A.; Graña, O.; Schwabe, R.F.; Perna, C.; Djouder, N. Hepatocellular Carcinomas Originate Predominantly from Hepatocytes and Benign Lesions from Hepatic Progenitor Cells. Cell Rep. 2017, 19, 584-600. [CrossRef]

129. Alqahtani, A.; Khan, Z.; Alloghbi, A.; Said Ahmed, T.S.; Ashraf, M.; Hammouda, D.M. Hepatocellular Carcinoma: Molecular Mechanisms and Targeted Therapies. Medicina 2019, 55, 526. [CrossRef]

130. Yang, J.D.; Hainaut, P.; Gores, G.J.; Amadou, A.; Plymoth, A.; Roberts, L.R. A global view of hepatocellular carcinoma: Trends, risk, prevention and management. Nat. Rev. Gastroenterol. Hepatol. 2019, 16, 589-604. [CrossRef]

131. El-Serag, H.B. Epidemiology of viral hepatitis and hepatocellular carcinoma. Gastroenterology 2012, 142, 1264-1273.e1261. [CrossRef]

132. Younossi, Z.M.; Ratziu, V.; Loomba, R.; Rinella, M.; Anstee, Q.M.; Goodman, Z.; Bedossa, P.; Geier, A.; Beckebaum, S.; Newsome, P.N.; et al. Obeticholic acid for the treatment of non-alcoholic steatohepatitis: Interim analysis from a multicentre, randomised, placebo-controlled phase 3 trial. Lancet 2019, 394, 2184-2196. [CrossRef]

133. Lazarus, J.V.; Colombo, M.; Cortez-Pinto, H.; Huang, T.T.; Miller, V.; Ninburg, M.; Schattenberg, J.M.; Seim, L.; Wong, V.W.S.; Zelber-Sagi, S. NAFLD-sounding the alarm on a silent epidemic. Nat. Rev. Gastroenterol. Hepatol. 2020, 17, 377-379. [CrossRef] [PubMed]

134. Welzel, T.M.; Graubard, B.I.; Quraishi, S.; Zeuzem, S.; Davila, J.A.; El-Serag, H.B.; McGlynn, K.A. Population-attributable fractions of risk factors for hepatocellular carcinoma in the United States. Am. J. Gastroenterol. 2013, 108, 1314-1321. [CrossRef] [PubMed]

135. Mittal, S.; El-Serag, H.B.; Sada, Y.H.; Kanwal, F.; Duan, Z.; Temple, S.; May, S.B.; Kramer, J.R.; Richardson, P.A.; Davila, J.A. Hepatocellular Carcinoma in the Absence of Cirrhosis in United States Veterans is Associated With Nonalcoholic Fatty Liver Disease. Clin. Gastroenterol. Hepatol. 2016, 14, 124-131.e121. [CrossRef] [PubMed]

136. Li, T.C.; Li, C.I.; Liu, C.S.; Lin, W.Y.; Lin, C.H.; Yang, S.Y.; Lin, C.C. Risk score system for the prediction of hepatocellular carcinoma in patients with type 2 diabetes: Taiwan Diabetes Study. Semin. Oncol. 2018, 45, 264-274. [CrossRef] [PubMed]

137. Hirosumi, J.; Tuncman, G.; Chang, L.; Görgün, C.Z.; Uysal, K.T.; Maeda, K.; Karin, M.; Hotamisligil, G.S. A central role for JNK in obesity and insulin resistance. Nature 2002, 420, 333-336. [CrossRef]

138. Balkwill, F.; Mantovani, A. Inflammation and cancer: Back to Virchow? Lancet 2001, 357, 539-545. [CrossRef]

139. Lleo, A.; de Boer, Y.S.; Liberal, R.; Colombo, M. The risk of liver cancer in autoimmune liver diseases. Adv. Med. Oncol. 2019, 11, 1758835919861914. [CrossRef]

140. Nowak, A.; Giger, R.S.; Krayenbuehl, P.A. Higher age at diagnosis of hemochromatosis is the strongest predictor of the occurrence of hepatocellular carcinoma in the Swiss hemochromatosis cohort: A prospective longitudinal observational study. Medicine 2018, 97, e12886. [CrossRef]

141. Ramadori, P.; Cubero, F.J.; Liedtke, C.; Trautwein, C.; Nevzorova, Y.A. Alcohol and Hepatocellular Carcinoma: Adding Fuel to the Flame. Cancers 2017, 9, 130. [CrossRef] 
142. Gouas, D.; Shi, H.; Hainaut, P. The aflatoxin-induced TP53 mutation at codon 249 (R249S): Biomarker of exposure, early detection and target for therapy. Cancer Lett. 2009, 286, 29-37. [CrossRef] [PubMed]

143. Golabi, P.; Fazel, S.; Otgonsuren, M.; Sayiner, M.; Locklear, C.T.; Younossi, Z.M. Mortality assessment of patients with hepatocellular carcinoma according to underlying disease and treatment modalities. Medicine 2017, 96, e5904. [CrossRef] [PubMed]

144. Berzigotti, A.; Reig, M.; Abraldes, J.G.; Bosch, J.; Bruix, J. Portal hypertension and the outcome of surgery for hepatocellular carcinoma in compensated cirrhosis: A systematic review and meta-analysis. Hepatology 2015, 61, 526-536. [CrossRef] [PubMed]

145. Teh, S.H.; Christein, J.; Donohue, J.; Que, F.; Kendrick, M.; Farnell, M.; Cha, S.; Kamath, P.; Kim, R.; Nagorney, D.M. Hepatic resection of hepatocellular carcinoma in patients with cirrhosis: Model of End-Stage Liver Disease (MELD) score predicts perioperative mortality. J. Gastrointest. Surg. 2005, 9, 1207-1215; discussion 1215. [CrossRef] [PubMed]

146. Sapisochin, G.; Bruix, J. Liver transplantation for hepatocellular carcinoma: Outcomes and novel surgical approaches. Nat. Rev. Gastroenterol. Hepatol. 2017, 14, 203-217. [CrossRef] [PubMed]

147. Xu, X.; Chen, J.; Wei, Q.; Liu, Z.-H.; Yang, Z.; Zhang, M.; Wang, G.-U.; Gao, J.; Yang, Z.; Guo, W.-E.; et al. EASL Clinical Practice Guidelines: Liver transplantation. J. Hepatol. 2016, 64, 433-485. [CrossRef]

148. Shiina, S.; Sato, K.; Tateishi, R.; Shimizu, M.; Ohama, H.; Hatanaka, T.; Takawa, M.; Nagamatsu, H.; Imai, Y. Percutaneous Ablation for Hepatocellular Carcinoma: Comparison of Various Ablation Techniques and Surgery. Can. J. Gastroenterol. Hepatol. 2018, 2018, 4756147. [CrossRef]

149. Lencioni, R.; de Baere, T.; Soulen, M.C.; Rilling, W.S.; Geschwind, J.F. Lipiodol transarterial chemoembolization for hepatocellular carcinoma: A systematic review of efficacy and safety data. Hepatology 2016, 64, 106-116. [CrossRef]

150. Keating, G.M. Sorafenib: A Review in Hepatocellular Carcinoma. Target. Oncol. 2017, 12, 243-253. [CrossRef]

151. Llovet, J.M.; Ricci, S.; Mazzaferro, V.; Hilgard, P.; Gane, E.; Blanc, J.-F.; de Oliveira, A.C.; Santoro, A.; Raoul, J.-L.; Forner, A.; et al. Sorafenib in Advanced Hepatocellular Carcinoma. N. Engl. J. Med. 2008, 359, 378-390. [CrossRef]

152. Al-Salama, Z.T.; Syed, Y.Y.; Scott, L.J. Lenvatinib: A Review in Hepatocellular Carcinoma. Drugs 2019, 79, 665-674. [CrossRef] [PubMed]

153. Bruix, J.; Qin, S.; Merle, P.; Granito, A.; Huang, Y.H.; Bodoky, G.; Pracht, M.; Yokosuka, O.; Rosmorduc, O.; Breder, V.; et al. Regorafenib for patients with hepatocellular carcinoma who progressed on sorafenib treatment (RESORCE): A randomised, double-blind, placebo-controlled, phase 3 trial. Lancet 2017, 389, 56-66. [CrossRef]

154. Finkelmeier, F.; Waidmann, O.; Trojan, J. Nivolumab for the treatment of hepatocellular carcinoma. Expert Rev. Anticancer 2018, 18, 1169-1175. [CrossRef] [PubMed]

155. Zhu, A.X.; Finn, R.S.; Edeline, J.; Cattan, S.; Ogasawara, S.; Palmer, D.; Verslype, C.; Zagonel, V.; Fartoux, L.; Vogel, A.; et al. Pembrolizumab in patients with advanced hepatocellular carcinoma previously treated with sorafenib (KEYNOTE-224): A non-randomised, open-label phase 2 trial. Lancet Oncol. 2018, 19, 940-952. [CrossRef]

156. Zhu, A.X.; Kang, Y.K.; Yen, C.J.; Finn, R.S.; Galle, P.R.; Llovet, J.M.; Assenat, E.; Brandi, G.; Pracht, M.; Lim, H.Y.; et al. Ramucirumab after sorafenib in patients with advanced hepatocellular carcinoma and increased $\alpha$-fetoprotein concentrations (REACH-2): A randomised, double-blind, placebo-controlled, phase 3 trial. Lancet Oncol. 2019, 20, 282-296. [CrossRef]

157. Sevic, I.; Spinelli, F.M.; Cantero, M.J.; Reszegi, A.; Kovalszky, I.; García, M.G.; Alaniz, L. The Role of the Tumor Microenvironment in the Development and Progression of Hepatocellular Carcinoma. In Hepatocellular Carcinoma; Tirnitz-Parker, J.E.E., Ed.; Codon Publications: Brisbane, QLD, Australia, 2019. [CrossRef]

158. Tanaka, Y.; Tateishi, R.; Koike, K. Proteoglycans Are Attractive Biomarkers and Therapeutic Targets in Hepatocellular Carcinoma. Int. J. Mol. Sci. 2018, 19, 3070. [CrossRef]

159. Ritz, T.; Krenkel, O.; Tacke, F. Dynamic plasticity of macrophage functions in diseased liver. Cell. Immunol. 2018, 330, 175-182. [CrossRef]

160. Higashi, T.; Friedman, S.L.; Hoshida, Y. Hepatic stellate cells as key target in liver fibrosis. Adv. Drug Deliv. Rev. 2017, 121, 27-42. [CrossRef] 
161. Mattyasovszky, S.G.; Wollstädter, J.; Martin, A.; Ritz, U.; Baranowski, A.; Ossendorf, C.; Rommens, P.M.; Hofmann, A. Inhibition of Contractile Function in Human Joint Capsule Myofibroblasts by Targeting the TGF- $\beta 1$ and PDGF Pathways. PLoS ONE 2016, 11, e0145948. [CrossRef]

162. Degroote, H.; Van Dierendonck, A.; Geerts, A.; Van Vlierberghe, H.; Devisscher, L. Preclinical and Clinical Therapeutic Strategies Affecting Tumor-Associated Macrophages in Hepatocellular Carcinoma. J. Immunol. Res. 2018, 2018, 7819520. [CrossRef]

163. Yeung, O.W.; Lo, C.M.; Ling, C.C.; Qi, X.; Geng, W.; Li, C.X.; Ng, K.T.; Forbes, S.J.; Guan, X.Y.; Poon, R.T.; et al. Alternatively activated (M2) macrophages promote tumour growth and invasiveness in hepatocellular carcinoma. J. Hepatol. 2015, 62, 607-616. [CrossRef] [PubMed]

164. Kuang, D.M.; Zhao, Q.; Peng, C.; Xu, J.; Zhang, J.P.; Wu, C.; Zheng, L. Activated monocytes in peritumoral stroma of hepatocellular carcinoma foster immune privilege and disease progression through PD-L1. J. Exp. Med. 2009, 206, 1327-1337. [CrossRef] [PubMed]

165. Wu, K.; Kryczek, I.; Chen, L.; Zou, W.; Welling, T.H. Kupffer cell suppression of CD8+ T cells in human hepatocellular carcinoma is mediated by B7-H1/programmed death-1 interactions. Cancer Res. 2009, 69, 8067-8075. [CrossRef] [PubMed]

166. Mueller, L.; Goumas, F.A.; Affeldt, M.; Sandtner, S.; Gehling, U.M.; Brilloff, S.; Walter, J.; Karnatz, N.; Lamszus, K.; Rogiers, X.; et al. Stromal fibroblasts in colorectal liver metastases originate from resident fibroblasts and generate an inflammatory microenvironment. Am. J. Pathol. 2007, 171, 1608-1618. [CrossRef] [PubMed]

167. Cirri, P.; Chiarugi, P. Cancer-associated-fibroblasts and tumour cells: A diabolic liaison driving cancer progression. Cancer Metastasis Rev. 2012, 31, 195-208. [CrossRef] [PubMed]

168. Ramachandran, P.; Pellicoro, A.; Vernon, M.A.; Boulter, L.; Aucott, R.L.; Ali, A.; Hartland, S.N.; Snowdon, V.K.; Cappon, A.; Gordon-Walker, T.T.; et al. Differential Ly-6C expression identifies the recruited macrophage phenotype, which orchestrates the regression of murine liver fibrosis. Proc. Natl. Acad. Sci. USA 2012, 109, E3186-E3195. [CrossRef]

169. Baeck, C.; Wei, X.; Bartneck, M.; Fech, V.; Heymann, F.; Gassler, N.; Hittatiya, K.; Eulberg, D.; Luedde, T.; Trautwein, C.; et al. Pharmacological inhibition of the chemokine C-C motif chemokine ligand 2 (monocyte chemoattractant protein 1) accelerates liver fibrosis regression by suppressing Ly-6C(+) macrophage infiltration in mice. Hepatology 2014, 59, 1060-1072. [CrossRef]

170. Chen, Y.; Zhang, S.; Wang, Q.; Zhang, X. Tumor-recruited M2 macrophages promote gastric and breast cancer metastasis via M2 macrophage-secreted CHI3L1 protein. J. Hematol. Oncol. 2017, 10, 1-13. [CrossRef]

171. Das, R.P.; Gandhi, V.V.; Singh, B.G.; Kunwar, A. Passive and Active Drug Targeting: Role of Nanocarriers in Rational Design of Anticancer Formulations. Curr. Pharm. Des. 2019, 25, 3034-3056. [CrossRef]

172. Kaps, L.; Nuhn, L.; Aslam, M.; Brose, A.; Foerster, F.; Rosigkeit, S.; Renz, P.; Heck, R.; Kim, Y.O.; Lieberwirth, I.; et al. In Vivo Gene-Silencing in Fibrotic Liver by siRNA-Loaded Cationic Nanohydrogel Particles. Adv. Healthc. Mater. 2015, 4, 2809-2815. [CrossRef]

173. Leber, N.; Kaps, L.; Yang, A.; Aslam, M.; Giardino, M.; Klefenz, A.; Choteschovsky, N.; Rosigkeit, S.; Mostafa, A.; Nuhn, L.; et al. $\alpha$-Mannosyl-Functionalized Cationic Nanohydrogel Particles for Targeted Gene Knockdown in Immunosuppressive Macrophages. Macromol. Biosci. 2019, 19, e1900162. [CrossRef] [PubMed]

174. Scodeller, P.; Simón-Gracia, L.; Kopanchuk, S.; Tobi, A.; Kilk, K.; Säälik, P.; Kurm, K.; Squadrito, M.L.; Kotamraju, V.R.; Rinken, A.; et al. Precision Targeting of Tumor Macrophages with a CD206 Binding Peptide. Sci. Rep. 2017, 7, 14655. [CrossRef] [PubMed]

175. Lopez-Pelaez, M.; Lamont, D.J.; Peggie, M.; Shpiro, N.; Gray, N.S.; Cohen, P. Protein kinase IKK $\beta$-catalyzed phosphorylation of IRF5 at Ser462 induces its dimerization and nuclear translocation in myeloid cells. Proc. Natl. Acad. Sci. USA 2014, 111, 17432-17437. [CrossRef] [PubMed]

176. Zhang, F.; Parayath, N.N.; Ene, C.I.; Stephan, S.B.; Koehne, A.L.; Coon, M.E.; Holland, E.C.; Stephan, M.T. Genetic programming of macrophages to perform anti-tumor functions using targeted mRNA nanocarriers. Nat. Commun. 2019, 10, 3974. [CrossRef] [PubMed]

177. Bobbin, M.L.; Rossi, J.J. RNA Interference (RNAi)-Based Therapeutics: Delivering on the Promise? Annu. Rev. Pharm. Toxicol. 2016, 56, 103-122. [CrossRef] [PubMed]

178. Zins, K.; Abraham, D. Cancer Immunotherapy: Targeting Tumor-Associated Macrophages by Gene Silencing. Methods Mol. Biol. 2020, 2115, 289-325. [CrossRef] 
179. Shobaki, N.; Sato, Y.; Suzuki, Y.; Okabe, N.; Harashima, H. Manipulating the function of tumor-associated macrophages by siRNA-loaded lipid nanoparticles for cancer immunotherapy. J. Control. Release 2020, 325, 235-248. [CrossRef]

180. McNelis, J.C.; Olefsky, J.M. Macrophages, immunity, and metabolic disease. Immunity 2014, 41, $36-48$. [CrossRef]

181. Loomba, R.; Lawitz, E.; Mantry, P.S.; Jayakumar, S.; Caldwell, S.H.; Arnold, H.; Diehl, A.M.; Djedjos, C.S.; Han, L.; Myers, R.P.; et al. The ASK1 inhibitor selonsertib in patients with nonalcoholic steatohepatitis: A randomized, phase 2 trial. Hepatology 2018, 67, 549-559. [CrossRef]

182. Tu, K.N.; Lie, J.D.; Wan, C.K.V.; Cameron, M.; Austel, A.G.; Nguyen, J.K.; Van, K.; Hyun, D. Osteoporosis: A Review of Treatment Options. Pharm. Ther. 2018, 43, 92-104.

183. Menshawy, A.; Mattar, O.; Abdulkarim, A.; Kasem, S.; Nasreldin, N.; Menshawy, E.; Mohammed, S.; Abdel-Maboud, M.; Gadelkarim, M.; El Ashal, G.G.; et al. Denosumab versus bisphosphonates in patients with advanced cancers-related bone metastasis: Systematic review and meta-analysis of randomized controlled trials. Support Care Cancer 2018, 26, 1029-1038. [CrossRef] [PubMed]

184. Van Acker, H.H.; Anguille, S.; Willemen, Y.; Smits, E.L.; Van Tendeloo, V.F. Bisphosphonates for cancer treatment: Mechanisms of action and lessons from clinical trials. Pharmathera 2016, 158, 24-40. [CrossRef] [PubMed]

185. Yu, X.; Chen, L.; Liu, J.; Dai, B.; Xu, G.; Shen, G.; Luo, Q.; Zhang, Z. Immune modulation of liver sinusoidal endothelial cells by melittin nanoparticles suppresses liver metastasis. Nat. Commun. 2019, 10, 574. [CrossRef] [PubMed]

186. Tang, T.; Sui, Y.; Lian, M.; Li, Z.; Hua, J. Pro-inflammatory activated Kupffer cells by lipids induce hepatic NKT cells deficiency through activation-induced cell death. PLoS ONE 2013, 8, e81949. [CrossRef] [PubMed]

187. Zhang, J.; Li, N.; Yang, L.; Xie, H.; Yang, Y.; Wang, H.; Wu, C.; Shen, T.; Zhu, Q. Bradykinin contributes to immune liver injury via B2R receptor-mediated pathways in trichloroethylene sensitized mice: A role in Kupffer cell activation. Toxicology 2019, 415, 37-48. [CrossRef]

188. Bros, M.; Nuhn, L.; Simon, J.; Moll, L.; Mailander, V.; Landfester, K.; Grabbe, S. The Protein Corona as a Confounding Variable of Nanoparticle-Mediated Targeted Vaccine Delivery. Front. Immunol. 2018, 9, 1760. [CrossRef]

(C) 2020 by the authors. Licensee MDPI, Basel, Switzerland. This article is an open access article distributed under the terms and conditions of the Creative Commons Attribution (CC BY) license (http://creativecommons.org/licenses/by/4.0/). 